\title{
Structure, geometry and kinematics of the northern Adula nappe (Central Alps)
}

\author{
Mattia Cavargna-Sani · Jean-Luc Epard • \\ Albrecht Steck
}

Received: 13 May 2013/Accepted: 28 October 2014/Published online: 21 November 2014

(C) Swiss Geological Society 2014

\begin{abstract}
The eclogitic Adula nappe of the Central Alps (cantons Graubünden and Ticino, Switzerland) displays an exceptionally complex internal structure with the particularity of enclosing numerous slices of Mesozoic cover rocks (Internal Mesozoic) within the Palaeozoic gneiss basement. This study is principally based on detailed lithological and structural mapping of selected areas of the northern Adula nappe. Specific focus was placed on the Mesozoic slivers embedded in pre-Mesozoic basement (Internal Mesozoic). The most pervasive structures are related to the Zapport deformation phase that is responsible for the development of a fold-nappe and ubiquitous northdirected shear. Locally, the structures in the upper and frontal part of the nappe can be assigned to the older ductile Ursprung phase. These earlier structures are only compatible with top-to-S shear movement. The superposition of the Ursprung and Zapport phases is responsible for the north-dipping internal duplex-like structure and the sliced aspect of the Northern and Central Adula nappe. We conclude that the Adula nappe represents a major shear
\end{abstract}

Editorial handling: S. M. Schmid and A. G. Milnes.

Electronic supplementary material The online version of this article (doi:10.1007/s00015-014-0175-7) contains supplementary material, which is available to authorized users.

M. Cavargna-Sani · J.-L. Epard · A. Steck

Institut des sciences de la Terre, Faculté des Géosciences et de l'Environnement, Bâtiment Géopolis, Université de Lausanne,

1015 Lausanne, Switzerland

Present Address:

M. Cavargna-Sani $(\bowtie)$

Dr. Baumer SA, Geologi Consulenti, Via ai molini 22,

6616 Losone, Switzerland

e-mail: mattia.cavargna@gmail.com zone involving the entire nappe and responsible for the emplacement of the Lower Penninic sediments and the Middle Penninic nappes in the eastern part of the Lepontine Dome.

Keywords Alpine orogeny · Fold structures · Nappe emplacement · High-pressure metamorphism . Switzerland · Pennine zone

\section{Introduction}

Eclogitic rocks in mountain belts are commonly associated with a suture zone tracing old subduction zones (Ernst 1971; Dal Piaz et al. 1972; Ernst 1973). Nappes containing eclogite relicts are found in the following structural positions in the Western and Central Alps: the Upper Penninic nappes, which represent the suture of the main branch of the Alpine-Tethys Ocean, and the more enigmatic eclogitic zone of the Lower Penninic nappes, which formed during the closure of the North Penninic paleogeographic domain (Oberhänsli 1994). The Adula nappe, situated in Switzerland on the boundary between cantons Graubünden and Ticino, is the most important eclogitic nappe amongst the Lower Penninic nappes. The present paper contributes towards a better understanding of the present-day geometry of the Adula nappe and the different deformation phases that have affected it. The northern Adula nappe is crucial to deciphering the kinematics of the nappe stack in the Lower Pennine zone.

The subduction-related high-pressure metamorphic conditions in the Adula nappe have been extensively studied (Heinrich 1986; Löw 1987; Meyre et al. 1999; Nagel et al. 2002a; Dale and Holland 2003; Hermann et al. 2006; Zulbati 2008, 2010). However, the structures related 
to the exhumation of the high-pressure rocks are still not well understood (Nagel 2008). Similarly, the overall geometry of the nappe produced by successive deformation phases has not been clearly described.

The structural complexity of this region requires a detailed multi-scale investigation. This study is mainly based on a detailed geologic and structural mapping of several representative key areas in the northern Adula nappe. Recent lithostratigraphic studies allow for a better understanding of map-scale structures and the stratigraphic significance of the infolded Mesozoic cover (CavargnaSani et al. 2010, 2014; Galster et al. 2012).

\section{Geological setting}

The Adula nappe is located in the eastern part of the Lepontine Dome and is one of the uppermost crystalline nappes in the Lower Penninic stack. This nappe is located on top of the Simano nappe (Fig. 1a, b). The two nappes are separated by a thin band of Mesozoic rocks and by the Soja nappe (Fig. 2), which is composed of basement rocks with a Triassic sedimentary cover (Egli 1966; Galster et al. 2010).

Several nappes and slices, composed mainly of Mesozoic sediments, crop out at the front of the Adula nappe, limited to the northwest by the Gotthard nappe. The various tectonic slices of the Grava nappe and the Terri-Lunschania zone are adjacent to sediments associated with Helvetic units (Baumer et al. 1961; Figs. 1, 2). Structurally, the Grava nappe and the units of the Terri-Lunschania zone are presently found underneath the front of the Adula nappe, but they must be rooted between the Adula nappe and the overlying Tambo nappe according to their stratigraphy and structure (Voll 1976; Galster et al. 2012). The stratigraphy of the Triassic series of the Terri-Lunschania zone evidences a lateral transition between the Helvetic and Briançonnais domains and the stratigraphy of the Jurassic series of these units reveals a complex basin opening history (Galster et al. 2010, 2012). The Grava nappe is mainly composed of North Penninic calcschists (Bündnerschiefer).

The Middle Penninic Tambo, Suretta and Schams nappes, structurally above the Adula nappe, are characterized by Briançonnais and Subbriançonnais type stratigraphy (Baudin et al. 1995; Rück 1995). The Adula nappe is separated from the Middle Penninic nappes by the Misox zone (Figs. 1, 2). This zone is made up of several nappes and slices (i.e., the Aul, Tomül and Grava nappes), composed mainly of metasedimentary clastic rocks (Bündnerschiefer) that were deposited in the North Penninic basin, and additionally of a few Jurassic ophiolitic rocks (Gannser 1937; Steinmann 1994; Liati et al. 2005). The Lower and Upper Valser slices lie directly on top of the Adula nappe and form the base of the Misox zone. They are composed of slices of various rock types such as gneiss, meta-basites, marble and calcschists (Steinmann 1994).

The southern part of the Adula nappe is separated from the Tambo nappe by the Forcola normal fault (Meyre et al. 1998; Fig. 1). Often, the Adula nappe is considered to be connected to the Gruf complex (e.g. Schmid et al. 1996). However, Galli et al. $(2011,2013)$ provided evidence that Gruf and Adula form two independent tectonic units. The (ultra-)high-pressure Cima Lunga unit is interpreted as being part of the Adula nappe based on its lithological similarity and structural position. However, Quaternary sediments in the valley of the Ticino river mask their connection.

The Adula nappe is famous for its metamorphic rocks and the occurrence of well-preserved eclogites and highpressure metapelites. The peak $\mathrm{P}-\mathrm{T}$-conditions of highpressure metamorphism in the Adula nappe increase from north to south. In the northern region (Vals area), the pressure and temperature peak conditions have been determined by various authors: $1.0-1.3 \mathrm{GPa}$ and 450-550 ${ }^{\circ} \mathrm{C}$ (Heinrich 1986; Löw 1987); $1.7 \mathrm{GPa}$ and 580-640 ${ }^{\circ} \mathrm{C}$ (Dale and Holland 2003); and $1.9 \mathrm{GPa}$ and $\sim 580{ }^{\circ} \mathrm{C}$ (Zulbati 2010). In the central part of the nappe (Alp da Confin, Alp da Trescolmen), the peak conditions are estimated at $\sim 2.2 \mathrm{GPa}$ and $\sim 650{ }^{\circ} \mathrm{C}$ (Heinrich 1986; Meyre et al. 1999; Dale and Holland 2003). In the southern part of the Adula nappe (Monte Duria garnet peridotites) and in the Cima Lunga nappe, the peak conditions reach $\sim 3.0 \mathrm{GPa}$ and $\sim 800{ }^{\circ} \mathrm{C}$ (Heinrich 1986; Nimis and Trommsdorff 2001, Hermann et al. 2006).

The units surrounding the Adula nappe have recorded subduction-related metamorphism of blueschist grade (Bousquet et al. 2002; Wiederkehr et al. 2008). The Misox zone between the Adula and Tambo nappes experienced a high-pressure metamorphic event of upper blueschist to eclogitic grade, as determined by the presence of eclogite preserved within the basic rocks (e.g., "Neu Wahli" outcrop; Gansser 1937; Santini 1992). The metasedimentary rocks northwest of the Adula nappe experienced highpressure-low-temperature metamorphism at approximately 1.2-1.4 GPa and 350-400 ${ }^{\circ} \mathrm{C}$, as evidenced by Mg-carpholite and chloritoid occurrences (Bousquet et al. 2002; Wiederkehr et al. 2008, 2011). The Tambo nappe recorded peak pressure conditions of $\sim 1.0-1.3 \mathrm{GPa}$ and temperatures ranging from $400{ }^{\circ} \mathrm{C}$ in the north to $550{ }^{\circ} \mathrm{C}$ in the central part of the nappe (Baudin and Marquer 1993). Peak pressure in the Simano nappe has been estimated at 1.0-1.2 GPa (Rütti 2003).

Subsequent to the high-pressure overprint, the Adula and surrounding nappes underwent Barrovian metamorphism ranging from greenschist facies in the north to upper amphibolite facies in the south. These conditions were 


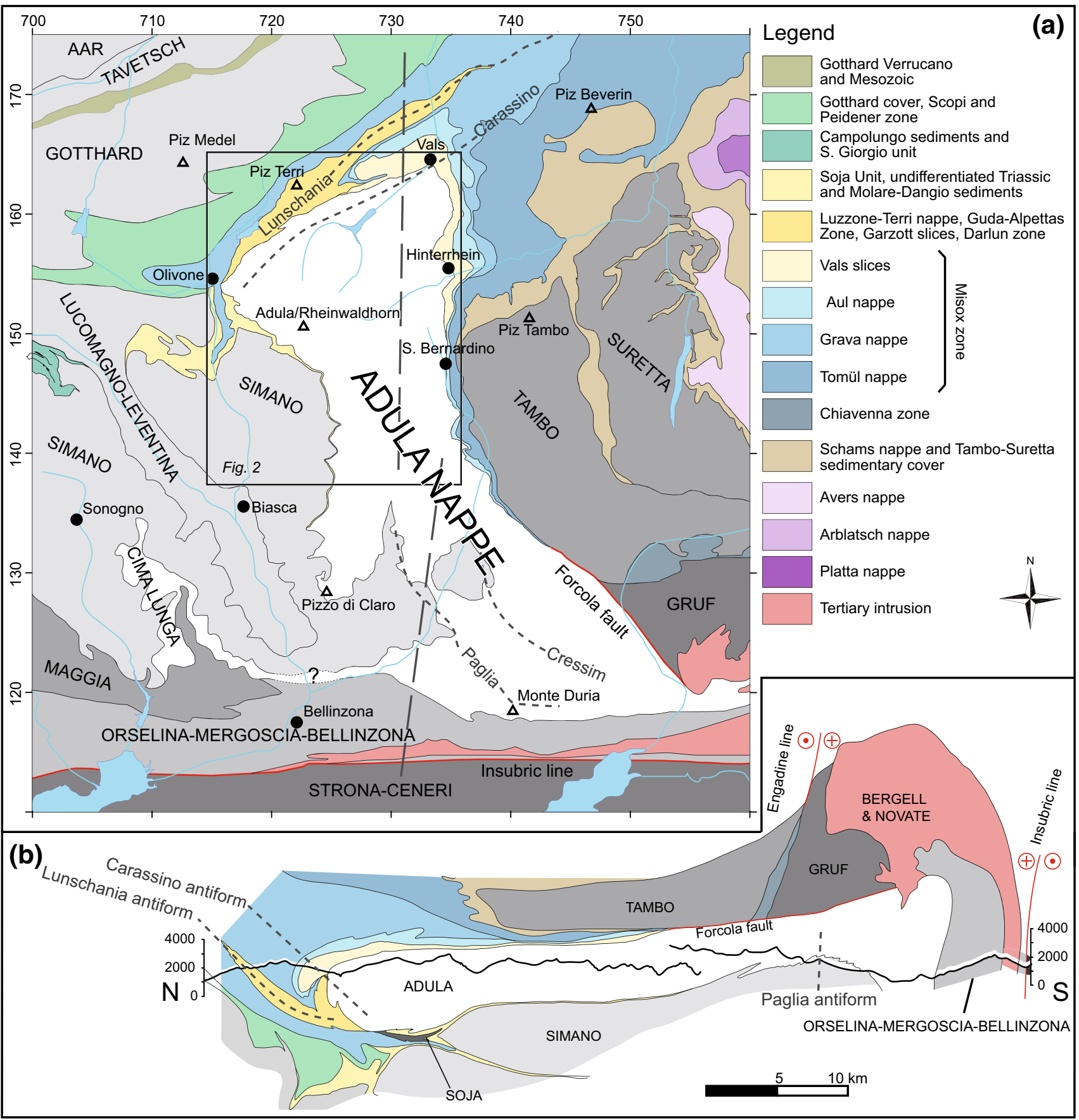

Fig. 1 Regional setting of the northern Adula nappe. a Tectonic map of the eastern Lepontine Alps. Basement nappes are shown in grey or white; sediments are shown in colour. Modified after Spicher (1980), Berger and Mercolli (2006), Steck et al. (2013) and Galster et al. (2012) and updated. The large rectangle indicates the limit of Fig. 2. The indicated traces represent the principal antiform of different phases. The coordinate system is the kilometric Swiss grid (CH 1903).

reached along a single continuous $\mathrm{P}-\mathrm{T}$ loop starting at high-pressure conditions (Löw 1987; Engi et al. 1995; Meyre et al. 1999; Nagel et al. 2002b; Dale and Holland 2003; Zulbati 2008). The isogrades related to Barrovian b Cross-section of the Eastern Lepontine Alps. Data are acquired from this work for the northern Adula nappe and compiled from Schmid et al. (1996), Nagel et al. (2002a), Berger et al. (2005), Galli et al. (2013) and Galster et al. (2012). The legend is the same as in (a) for the tectonic units outside the Adula nappe. The trace of the cross-section is indicated on the map (a)

metamorphism crosscut the Adula nappe and surrounding nappes, although reached through different $\mathrm{P}-\mathrm{T}$ paths, suggesting a thermal peak which post-dated nappe emplacement (see details in Nagel 2008). 


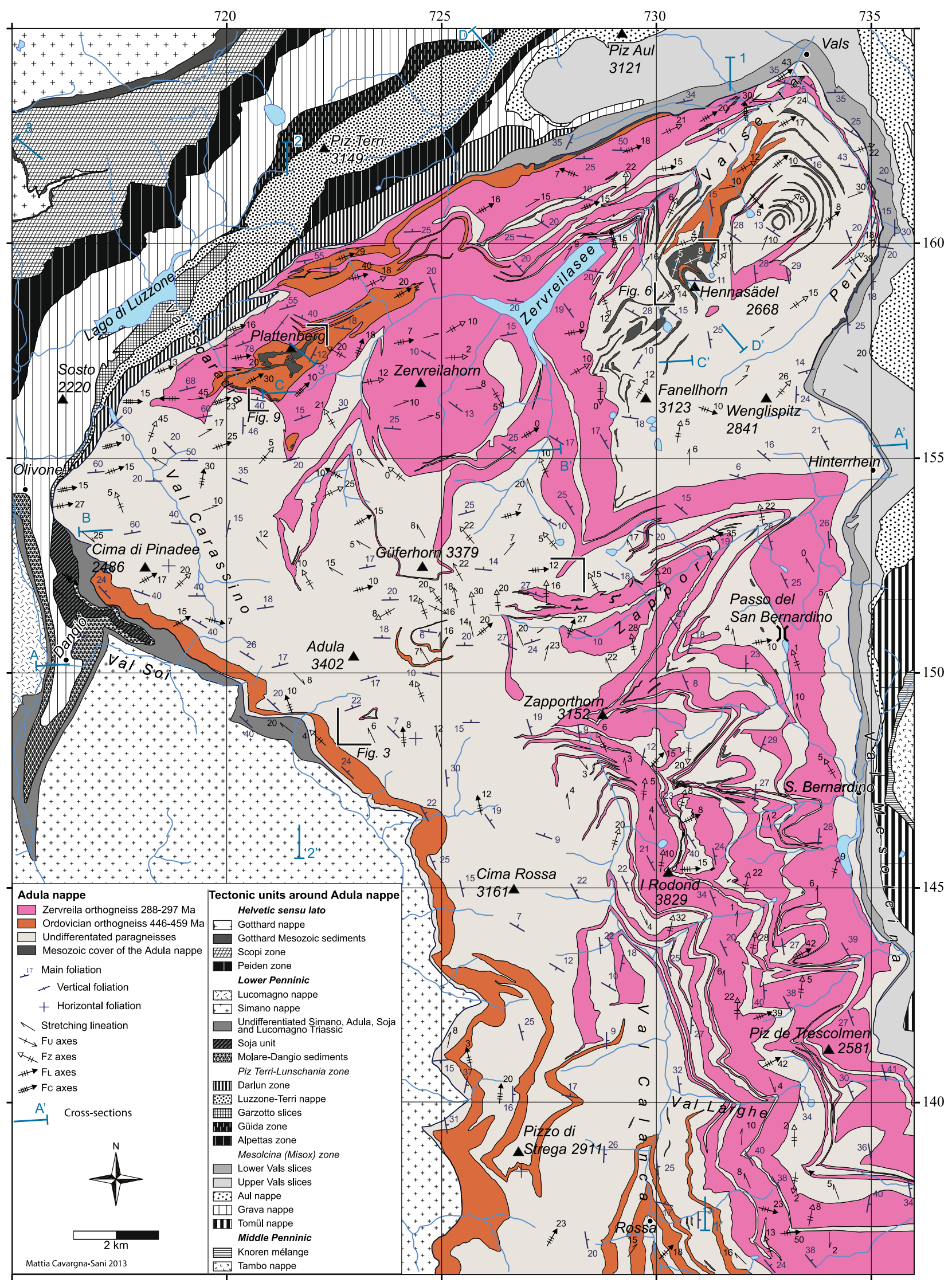


४Fig. 2 Geological map of the northern Adula nappe. New area mapped by M. Cavargna-Sani (this work) and compilation of maps from Jenny et al. (1923), Kündig (1926), Van der Plas (1959), Egli (1966), Frey (1967), Pleuger et al. (2003), Berger and Mercolli (2006), Arnold et al. (2007) and Swisstopo (2012). Maps in the unpublished Diploma and MSc theses mentioned in the Acknowledgements have also been consulted. The coordinate system is the kilometric Swiss grid (CH 1903). Rectangles indicate the detailed map location (Figs. 3, 6, 9)

The difference in peak pressure conditions between the Adula nappe and the structurally higher nappes (e.g. Tambo nappe) is the main argument for proposing an extrusion model for the emplacement of the Adula nappe (e.g., Schmid et al. 1996). However, the conversion of the high-pressure record to burial depth has recently been questioned. The high-pressure values estimated in the Adula nappe can also be partly explained by tectonic overpressure (Petrini and Podladchikov 2000; Mancktelow 2008; Schmalholz and Podladchikov 2013; Pleuger and Podladchikov 2014), questioning the extrusion model.

The age of high-pressure metamorphism in the Adula nappe has been the subject of recent debates (Liati et al. 2009; Zulbati 2010; Herwartz et al. 2011). In the northern part of the nappe, P-T estimates were obtained from Mesozoic metapelites in the Hennasädel locality (Fig. 2; Löw 1987; Zulbati 2008; Wiederkehr et al. 2011). The Alpine age of this metamorphism is certain. Nevertheless it appears that at least some of these eclogites were part of the Palaeozoic basement and hence exhibit a polymetamorphic history. Liati et al. (2009) dated the high-pressure metamorphism to the Devonian and mid-Carboniferous, based on the analysis of zircon metamorphic rims. They reported an Alpine age of 30-32 Ma for the peak temperature conditions in zircons of the central part of the nappe. Herwartz et al. (2011) obtained Carboniferous as well as Eocene ages for eclogitic garnets in the central part of the nappe. This finding confirms the presence of Alpine eclogites in the Palaeozoic mafic rocks of the central Adula nappe.

The Adula nappe has its own Mesozoic sedimentary cover sequence that is locally deeply infolded within the basement (Heim 1891; Jenny et al. 1923), classically called Internal Mesozoic (Heim 1891; Heinrich 1983). In the Jurassic, the paleogeographic position of the Adula domain is located at the distal European (southern Helvetic) margin (Steinmann 1994; Cavargna-Sani et al. 2010; Galster et al. 2012).

The Adula basement is composed of several Palaeozoic formations (undifferentiated paragneisses in Fig. 2), as outlined by Cavargna-Sani et al. (2014) and briefly described below. The Salahorn Fm. is composed of Cambrian sediments associated with a few orthogneisses. The
Trescolmen Fm. is most likely a chaotic metamorphic formation composed of meta-basaltic blocs in a metapelitic matrix. The ages ( $\mathrm{U} / \mathrm{Pb}$ on zircons) obtained in this chaotic formation span from 460 to $370 \mathrm{Ma}$. The Garenstock augengneiss and the Rossa orthogneiss are Ordovician granites (grouped as Ordovician orthogneisses in Fig. 2). The Heinisch Stafel Fm. is composed of Ordovician volcanoclastic sediments. The Permian Zervreila granite is intrusive into the pre-structured basement formed by juxtaposition of the formations presented above (Fig. 2). The complex pre-Mesozoic evolution of the Adula basement needs to be considered when studying the Alpine structures. The monocyclic Permian granites and the Mesozoic sediments are good markers for separating the Alpine deformations features from older ones.

A description of the larger regional setting of the Lepontine Alps can be found in Steck et al. (2013), as well as in the explanatory notes of Berger et al. 2005 to the tectonic map of Berger and Mercolli (2006).

\section{Structures of the northern Adula nappe}

\subsection{Introduction}

The overall structure of the Adula nappe is a north-vergent fold-nappe rooted between the zone of Orselina-Mergoscia-Bellinzona and the Simano nappe (Fig. 1b; Jenny et al. 1923; Schmid et al. 1996). The nappe is refolded by southverging post-nappe folds in the southern region (Fig. 1b; Nagel et al. 2002a). The exceptionally complex geometry and the presence of the Internal Mesozoic are distinctive features of the internal structure of the Adula nappe.

The Alpine deformation phases are listed below and will be detailed in the following chapters. The Ursprung phase $\left(D_{U}\right)$ is the earliest phase that has been observed. Folds $\left(\mathrm{F}_{\mathrm{U}}\right)$ are associated to a schistosity $\left(\mathrm{S}_{\mathrm{U}}\right)$. Synclines of Mesozoic cover are attributed to this deformation phase. The Zapport phase $\left(\mathrm{D}_{\mathrm{Z}}\right.$; Löw 1987) corresponds to the main pervasive structure. The Zapport deformation phase $\left(D_{Z}\right)$ forms the main pervasive schistosity $\left(S_{Z}\right)$, associated with a stretching lineation $\left(\mathrm{L}_{Z}\right)$ and widespread isoclinal folds $\left(\mathrm{F}_{\mathrm{Z}}\right)$. The Leis phase $\left(\mathrm{D}_{\mathrm{L}}\right.$; Löw 1987) is expressed by folds $\left(F_{L}\right)$ and locally by a cleavage $\left(S_{L}\right)$ associated with a stretching lineation $\left(\mathrm{L}_{\mathrm{L}}\right)$. The last Carassino phase $\left(\mathrm{D}_{\mathrm{C}}\right.$; Löw 1987) mainly forms the northwest-vergent antiform at the front of the nappe. The deformation phases described above all affect the Palaeozoic basement, the younger Permian granites and the Mesozoic sediments; they are unambiguously the product of the Alpine deformation.

Within the northern Adula nappe, the Zapport Valley area, the Hennasädel area and the Plattenberg area are of primary importance to the understanding of the structure 


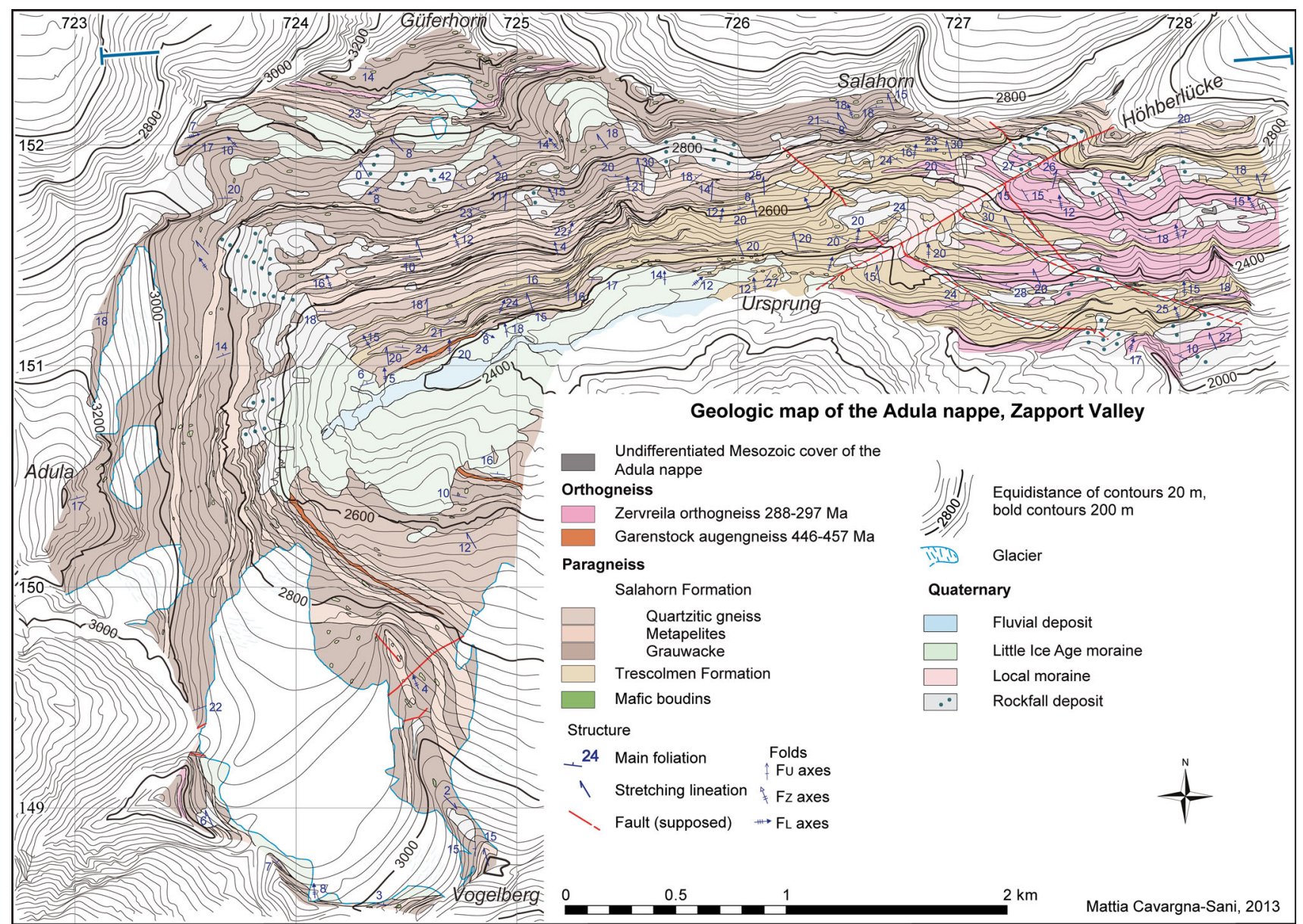

Fig. 3 Geological map of the Zapport Valley area. The type locality of Ursprung (Ursprung deformation phase) is indicated. The coordinate system is the kilometric Swiss grid (CH 1903)

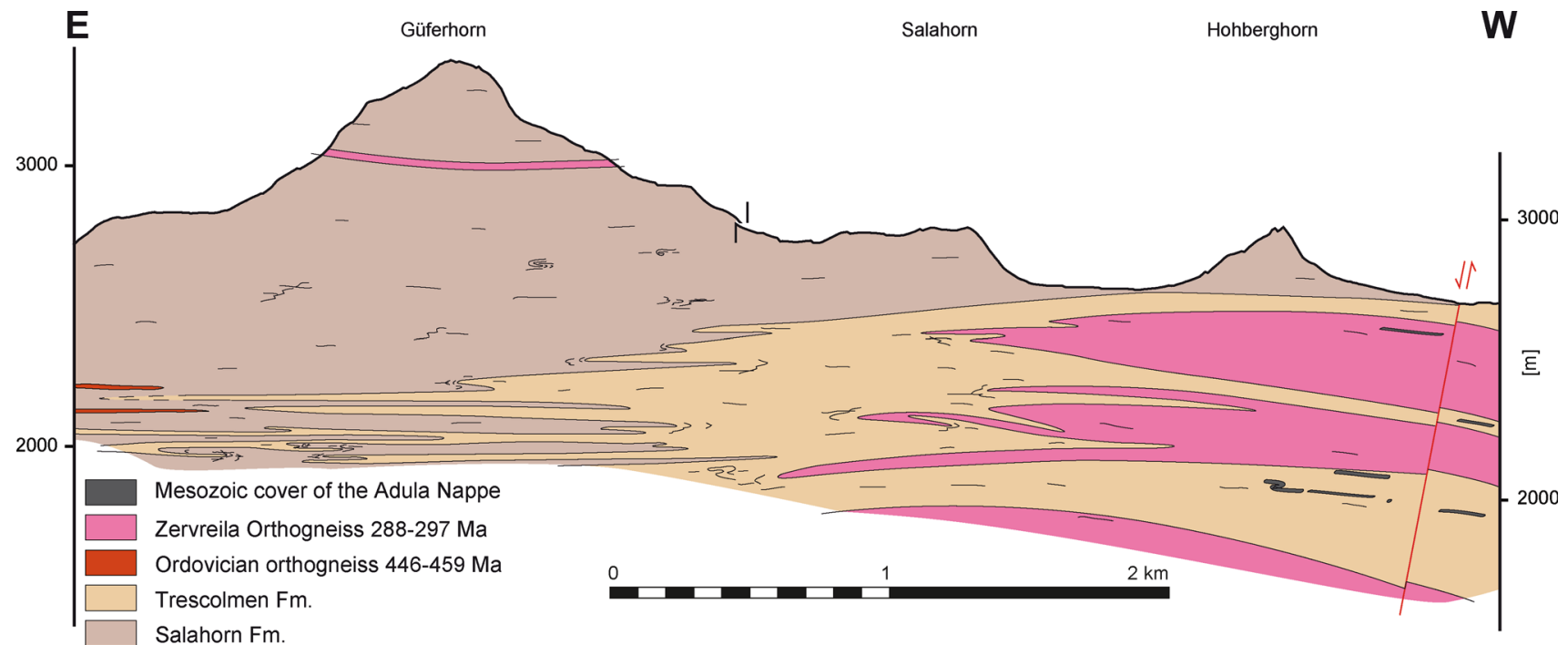

Fig. 4 Cross-section of the Zapport Valley area. The cross-section trace is indicated in Fig. 3 

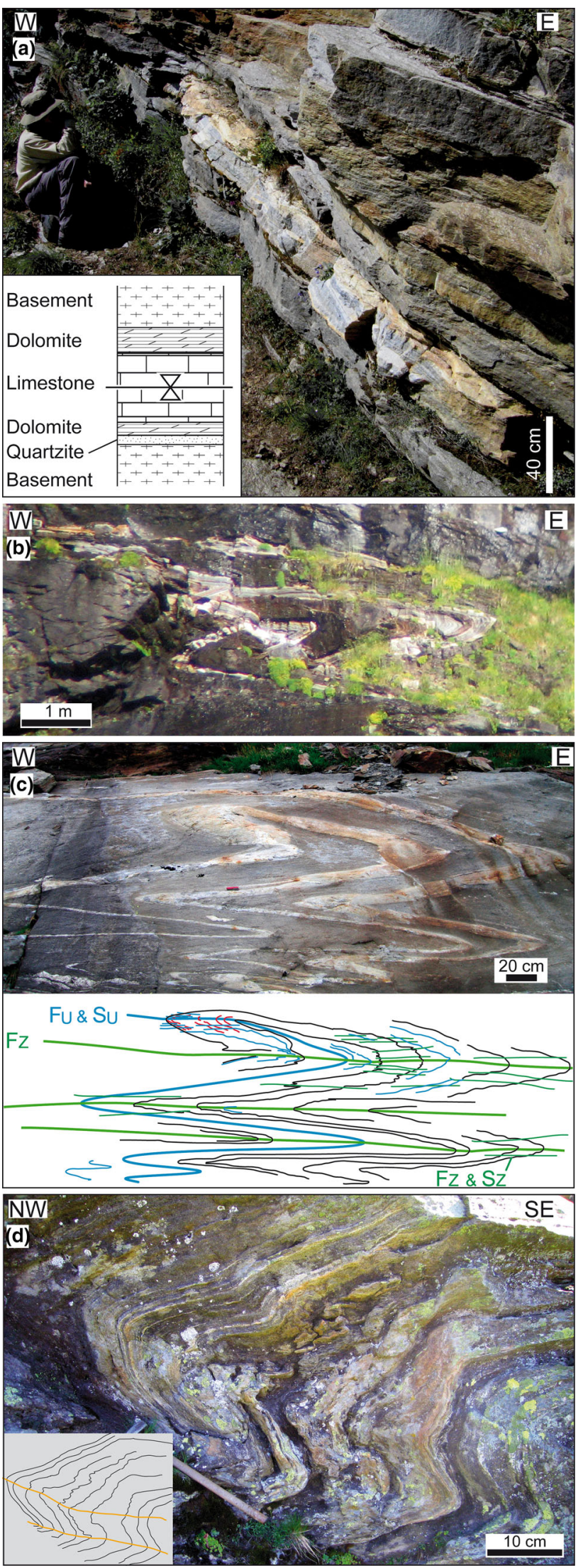

४Fig. 5 Outcrop-scale structures in the Zapport Valley area. a Internal Mesozoic layer constituted by a narrow syncline (729900/151900) b Internal Mesozoic layer folded by $\mathrm{F}_{\mathrm{Z}}(727500 / 151250)$ c Interference pattern produced by superimposed folding between $F_{U}$ and $F_{Z}$ and interpretative schema (725950/151470). d Leis phase fold (727680/151150)

and geometry. A general map and the location of these key area, which were mapped in detail, are shown in Fig. 2 and are described in the following sections.

\subsection{Zapport Valley}

The Zapport Valley area (Fig. 3) was mapped at the 1:10,000 scale. This part of the valley is oriented perpendicular to the $\mathrm{F}_{\mathrm{Z}}$ (Zapport) fold axes and provides excellent outcrops of a wide segment in the deepest structural level of the central Adula nappe. This area remains mostly unaffected by the later deformation phases. The $D_{U}, D_{Z}$ and $\mathrm{D}_{\mathrm{L}}$ deformation phases are visible at the outcrop scale. $\mathrm{F}_{\mathrm{Z}}$ are obvious at the map scale and are the dominant structures of the area (Fig. 4).

$\mathrm{D}_{\mathrm{U}}$ (Ursprung) structures are characterised by folds associated with an axial plane schistosity. Synclines made of autochthonous Mesozoic cover (Fig. 5a, b) are interpreted as $\mathrm{D}_{\mathrm{U}}$ folds. These synclines are locally refolded by $\mathrm{F}_{\mathrm{Z}}$ (Fig. 5b). $\mathrm{F}_{\mathrm{U}}$ folds are isoclinal and range from a few centimetres to map-scale in amplitude. The fold axes are approximately north-south, almost certainly reoriented parallel to $L_{Z}$. These folds form type 3 (Ramsay 1967) fold interference patterns with the subsequent $F_{Z}$ folds (Fig. 5c). The folds of the $D_{U}$ phase show a relict schistosity refolded in their hinges (Fig. 5c) most likely related to an early shearing related to the same phase (Ramsay and Allison 1979). $S_{U}$ is the axial surface schistosity of the previously described folds (Fig. 5a, c). It can also be found as a relict structure refolded in the hinges of the $F_{Z}$ (Fig. 5c, d).

$\mathrm{F}_{\mathrm{Z}}$ forms an isoclinal recumbent west-closing fold at the scale of the whole Zapport valley section (Fig. 4) with a north-south fold axis parallel to $\mathrm{L}_{\mathrm{Z}}$ (Figs. 3, 5b). These folds refold the earlier $D_{U}$ structures (Fig. $5 b, c$ ). $S_{Z}$ forms the axial plane schistosity associated with $\mathrm{F}_{Z}$, forming the main fabric in this area. The schistosity carries a northsouth oriented mineral lineation associated with top-to-N shear criteria (principally sigma structures).

In Zapport valley, $\mathrm{D}_{\mathrm{L}}$ is expressed by centimetre- to decametre-scale, open to closed, north- to northwest-vergent folds (Fig. 5d). The fold axes plunge towards the east to north-northeast (see map, Fig. 2), and the axial planes dip towards the south to southeast with a variable dip. No map-scale folds have been observed in the area. The $S_{L}$ 


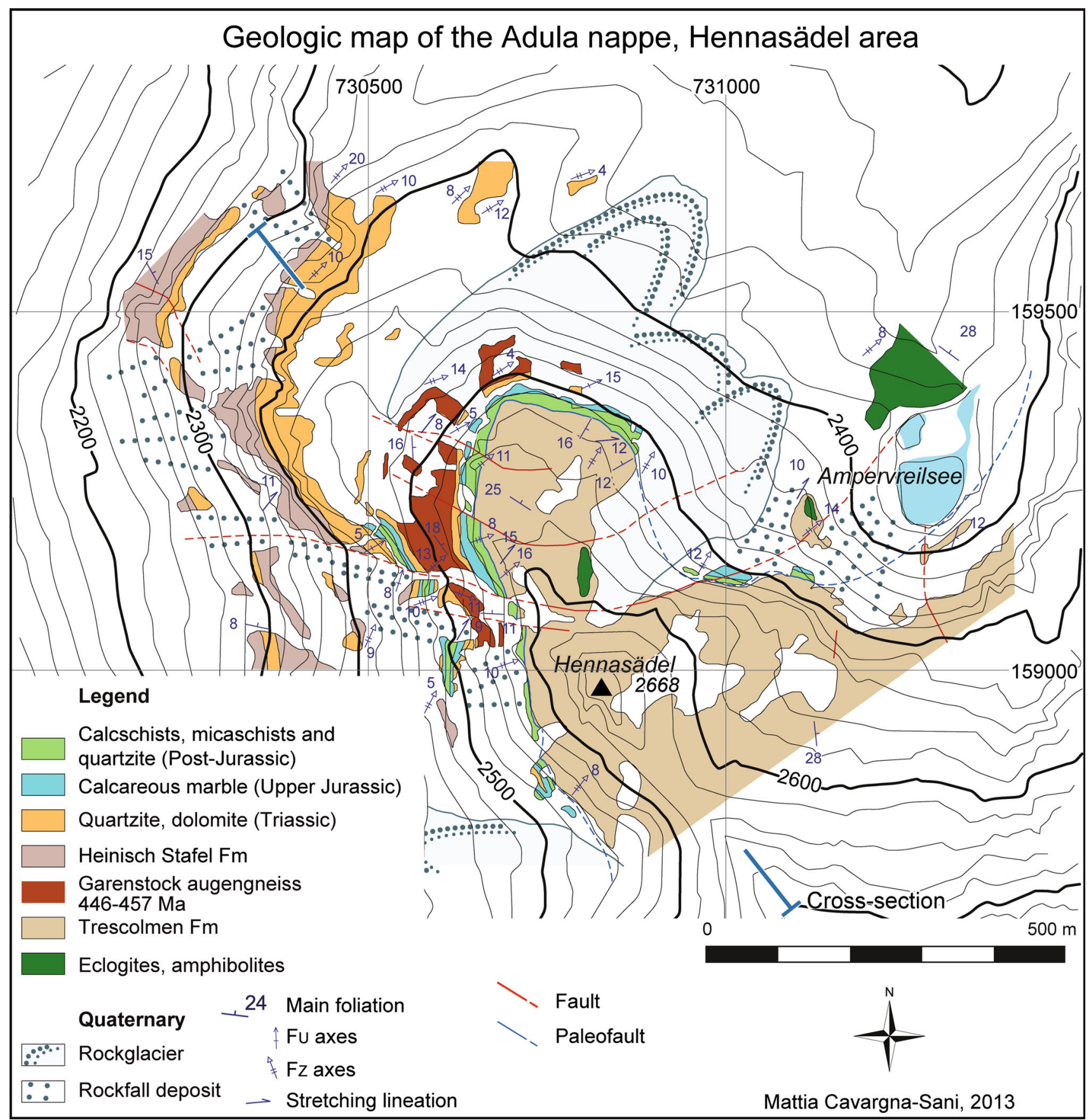

Fig. 6 Geological map of the Hennasädel area. The coordinate system is the metric Swiss grid (CH 1903)

crenulation cleavage appears restricted to a few fold hinges. No stretching lineation associated with $D_{L}$ has been observed.

\subsection{Hennasädel}

Hennasädel hill is located on the southeast slope of the Upper Valsertal, above the Zervreila dam. This area is represented on the 1:25,000 Swisstopo atlas map Vals
(Arnold et al. 2007). The hill was mapped at a 1:5,000 scale (Fig. 6) to provide a better lithostratigraphic and structural understanding. The cross-section (Fig. 7) is drawn perpendicular to the $\mathrm{F}_{\mathrm{Z}}$ fold axes and $\mathrm{L}_{\mathrm{Z}}$. The Hennasädel exposes one of the most interesting sequences of the Adula Internal Mesozoic.

The Mesozoic series of the Hennasädel represent the sedimentary cover of the Adula nappe, with clearly identified sedimentary formations. The lithostratigraphy is 


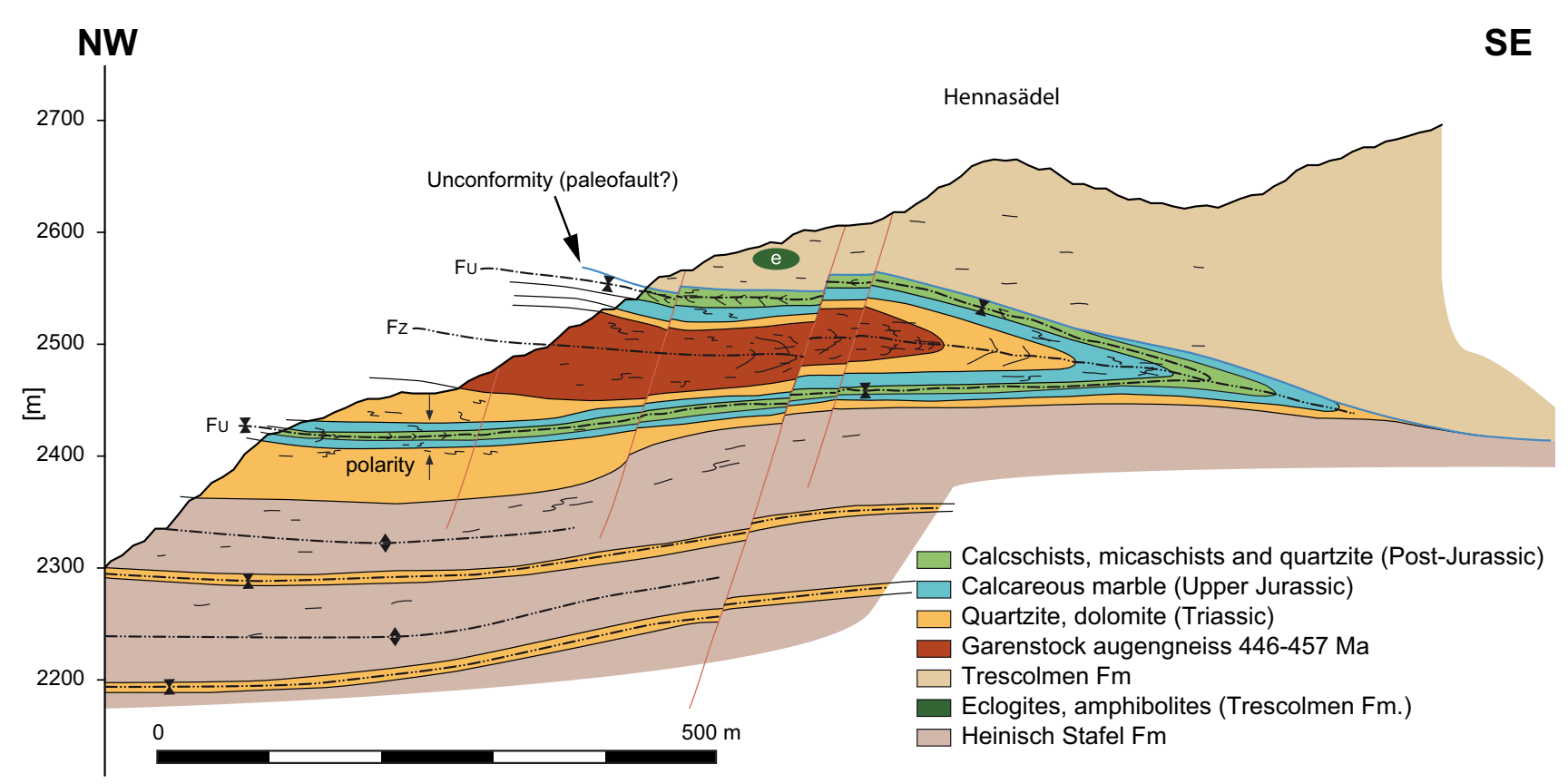

Fig. 7 Cross-section of the Hennasädel area. The cross-section trace is indicated in Fig. 6

described in detail in the Electronic Supplementary Material 1 and 2 and in Galster et al. (2012). The Mesozoic series are in stratigraphic contact with the pre-Triassic Heinisch Stafel Fm. and the Garenstock augengneiss briefly described in the introduction.

$\mathrm{F}_{\mathrm{Z}}-\mathrm{F}_{\mathrm{U}}$ fold interference patterns can be observed both at the outcrop scale (Fig. 8) and map scale (Fig. 7). The major map scale $\mathrm{F}_{\mathrm{U}}$ is identified based on stratigraphic and structural (i.e., second order folds) criteria (Fig. 8a, b). This $\mathrm{F}_{\mathrm{U}}$ syncline is the first-generation fold in the Hennasädel outcrop. It is associated with a $\mathrm{S}_{\mathrm{U}}$ schistosity (Fig. 8b). The most obvious structure of the Hennasädel is an $\mathrm{F}_{\mathrm{Z}}$ isoclinal recumbent southeast-closing fold with the Garenstock augengneiss in its core (Fig. 7). This structure folds the $\mathrm{F}_{\mathrm{U}}$ syncline described above. Several secondorder $\mathrm{F}_{\mathrm{Z}}$ folds are associated with the map-scale first-order fold.

Synclines underlined by Triassic dolomites are frequent between Hennasädel and Wissgrätli (Fig. 2). The stratigraphic contact with the basement is frequently marked by Triassic quartzites. These synclines are essentially $F_{Z}$ folds that close to the southeast in accordance with the general facing direction of these folds towards the northwest. A stretching lineation plunging towards the northeast is related to the $\mathrm{D}_{\mathrm{Z}}$ deformations. The shear sense observed parallel to this lineation is top-to-NE. In addition to the usual kinematic indicators (i.e., sigma clasts in the Garenstock Augengneiss), the snowball garnets observed in quartzitic-micaschists of the cover series are spectacular (Fig. 8d, e). The identical top-to-N shear sense criteria are observed in both limbs of the map-scale $F_{Z}$ fold. This observation, with the northeast-southwest fold axis, supports a reorientation of the structures during the final step of $\mathrm{D}_{\mathrm{Z}}$. Later $\mathrm{D}_{\mathrm{L}}$ and $\mathrm{D}_{\mathrm{C}}$ deformations are only weakly discernible on Hennasädel hill. This area is essentially devoid of these deformation phases; they are more developed to the northwest.

The contact with the Trescolmen Fm. on the top of the isoclinal fold in Fig. 7 is not clearly in stratigraphic contact with the Mesozoic. However, there is no sign of post- $\mathrm{S}_{Z}$ shear indicators or brittle fracturing, as would be expected if this structure was a late, post- $\mathrm{D}_{\mathrm{Z}}$ thrust. We propose that this geometry indicates a paleofault.

\subsection{Plattenberg}

Of primary interest in the Plattenberg area (Figs. 9, 10) are the impressive outcrops of Internal Mesozoic (Fig. 11a) with multiple folding visible at map scale (Figs. 10, 11b). Heim (1891) described the dolomites between Plattenberg and Passo Sorreda, and Jenny et al. 1923 and Egli (1966) mapped this area in detail. Löw (1987) provided the first modern structural analysis of the area and defined the commonly used deformation phases. The cross-section (Fig. 10) is based on the new mapping at the 1:5,000 scale (Fig. 9) and the new structural analysis.

The Garenstock augengneiss forms the Palaeozoic basement in this area. This augengneiss contains a few eclogite boudins. The Mesozoic sediments of the Plattenberg represent the stratigraphical cover of the Adula nappe 

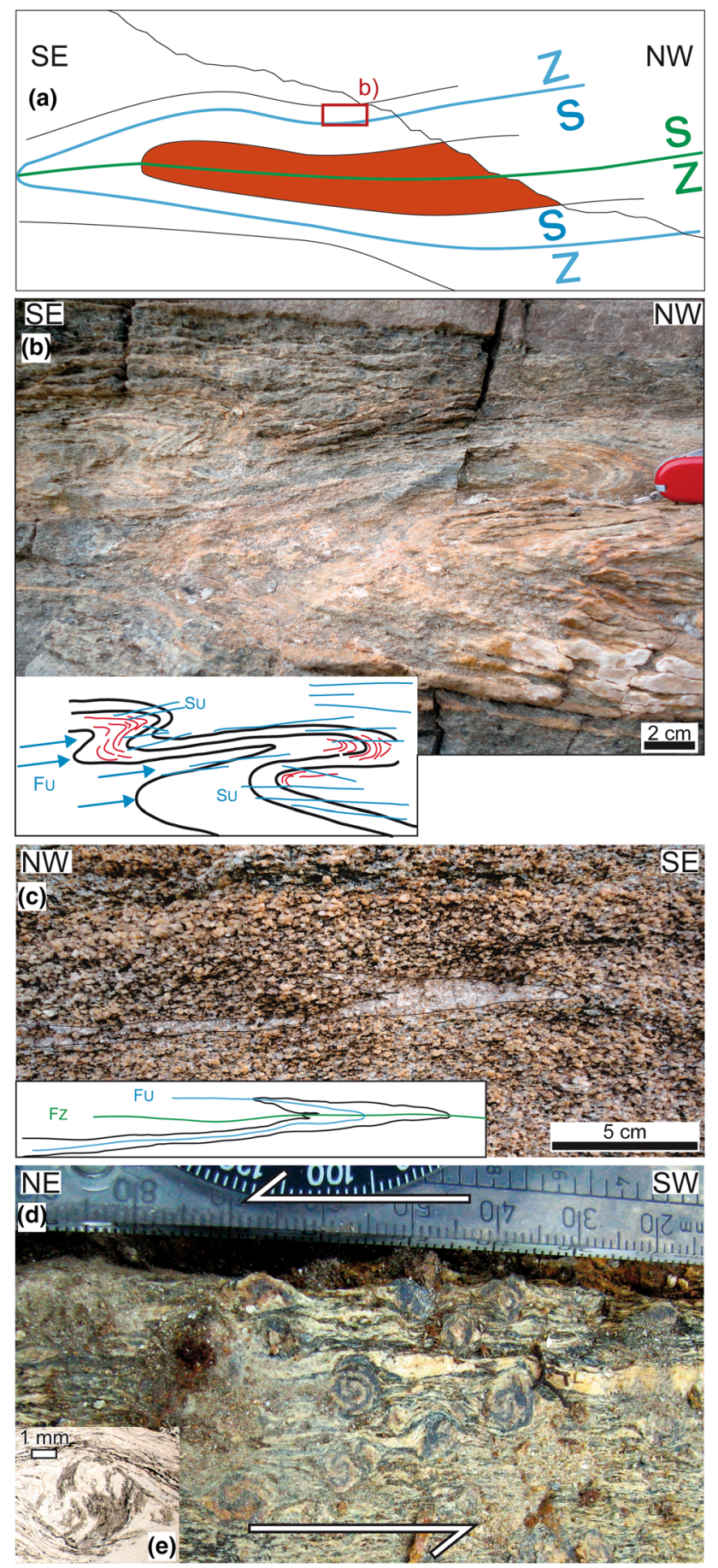

Fig. 8 Outcrop-scale structures in the Hennasädel area. a Position of $8 \mathrm{~b}$ (red rectangle); schematic indication of the vergence of the $\mathrm{F}_{\mathrm{U}}$ and $\mathrm{F}_{\mathrm{Z}}$ second-order folds; the cross-section has the same orientation as in (a). b Ursprung phase second order folds (730840/159350) c $\mathrm{F}_{\mathrm{U}}-\mathrm{F}_{\mathrm{Z}}$ fold interference pattern (730640/159200). d Snowball garnet porphyroblasts in the quartzitic schists of the Mesozoic cover indicating the top-to-NE shear sense of the Zapport phase (730830/ 159340). e Snowball garnet in a thin section

with well-defined formations (Fig. 11a, Online Resources 1 and 2, Cavargna-Sani et al. 2010). The basement-cover contact is underlined by a transgressive quartzite representing the base of the Triassic (Fig. 11a), with paleosolic and clear weathering alteration of the basement under the contact. A detailed description can be found in Online Resources 1 and 2 and in Cavargna-Sani et al. (2014).

The structure of the area is dominated by map-scale folds affecting Mesozoic sequence and basement gneisses. The oldest obvious structures visible in the Plattenberg area are $\mathrm{D}_{\mathrm{U}}$ isoclinal folds (Fig. 11b). These folds are associated with an $\mathrm{S}_{\mathrm{U}}$ schistosity. The quartzite and dolomitic breccia of the Plattenberg Fm is very suitable for structural geology analysis; this formation preserved a pronounced bedding and is less deformed by later $\mathrm{D}_{\mathrm{L}}$ deformation. The $\mathrm{F}_{\mathrm{U}}$ folds are clearly refolded by $\mathrm{F}_{\mathrm{Z}}$ isoclinal folds, as can be observed at the outcrop scale (Fig. 11b) and map scale (Figs. 9, 10). Outside the interference patterns, the main pervasive schistosity in most rock types is attributed to $S_{Z}$. The $F_{Z}$ folds form clear interferences with the younger $F_{L}$ at outcrop scale (Fig. 11b) and map scale (Fig. 10). Leis phase folds are the main structural feature of this area, and they form kilometre-scale closed to tight folds (Fig. 10). The fold geometry is strongly influenced by the competence contrast between the different rock types (especially between the more competent dolomite and the Garenstock Augengneiss). An axial plane $S_{L}$ cleavage is developed in $F_{L}$ fold hinges, varying from a crenulation cleavage to a mineral foliation (Fig. 11c, d). A northeast-plunging, stretching $\mathrm{L}_{\mathrm{L}}$ lineation is sometimes associated with $\mathrm{S}_{\mathrm{L}}$. The late $D_{C}$ forms rather open folds locally associated with a crenulation cleavage. This phase refolds all the previously described fold phases. Fold interferences can also be observed at the map scale (Fig. 10).

The autochthony of the cover series with respect to the basement (Fig. 11a) enables us to distinguish and interpret the earlier deformation phases. Löw (1987) defined the Sorreda phase as one that is responsible for the tectonic inclusion of Mesozoic slices in the basement rocks. However, these basement-cover contacts are not a tectonic. The formation of the Internal Mesozoic in the frontal part of the nappe is infolded due to $F_{U}$ and subsidiary $F_{Z}$ synclines, the Mesozoic cover being in stratigraphic contact with the basement. The overall Plattenberg Internal Mesozoic outcrops can be roughly described as an $\mathrm{F}_{\mathrm{U}}$ syncline refolded by the subsequent deformation phases. The original connection of this syncline to a hypothetical "external Mesozoic" is eroded. The geometry of the folding interference pattern proposed at the map scale by our cross-section (Fig. 10) can also be confirmed at the outcrop scale (Fig. 11b).

\subsection{Nappe-scale geometry and structures}

The investigations at the scale of the entire Adula nappe are primarily based on the nappe-scale cross-sections 


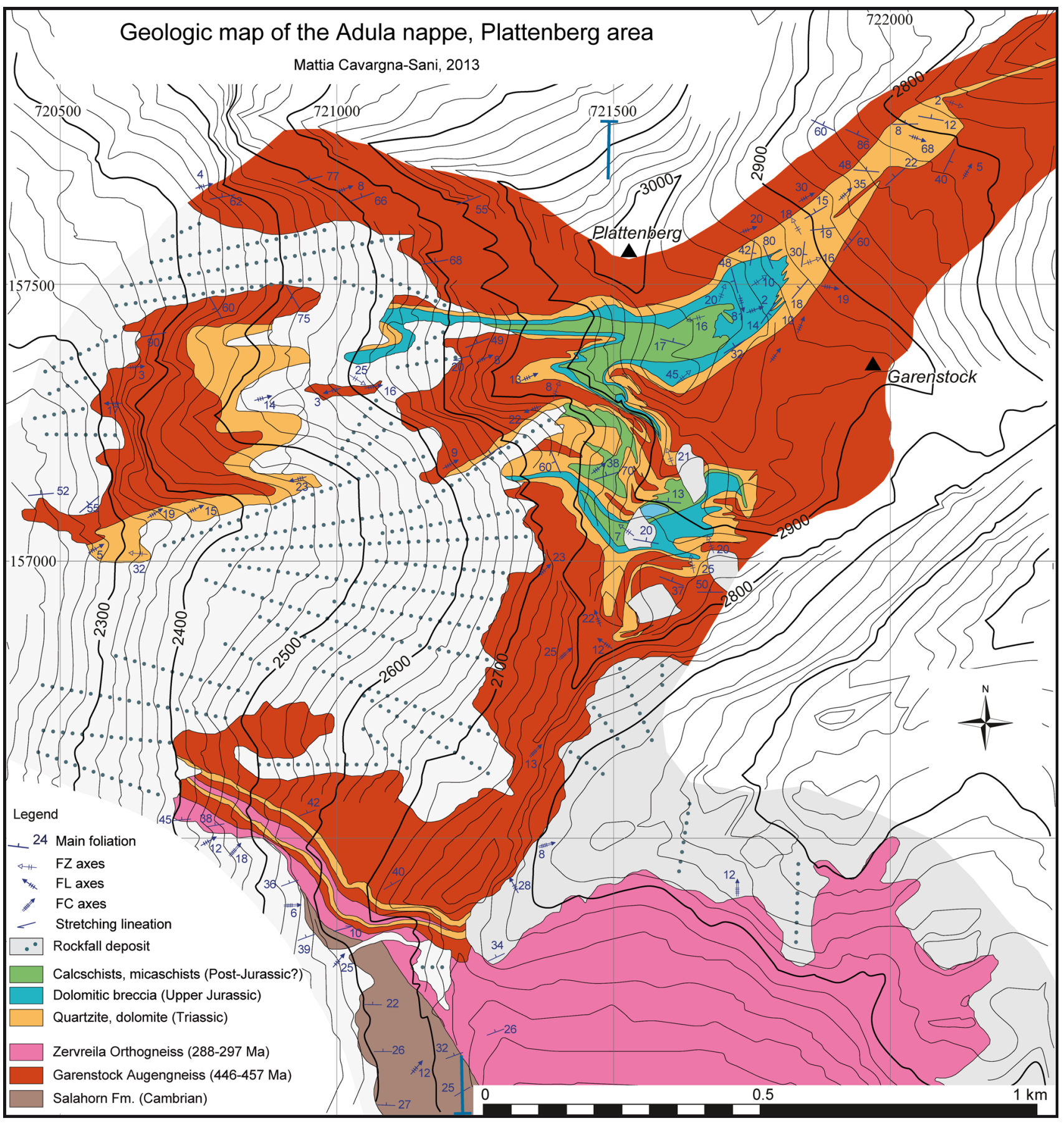

Fig. 9 Geological map of the Plattenberg area. The coordinate system is the metric Swiss grid (CH 1903)

shown in Fig. 12. The orientation of the main structural features (fold axes, lineations and schistosity) is indicated on the geological map (Fig. 2) and summarised in stereographic projections (Fig. 13). The axial traces of the main map-scale folds of the northern Adula nappe are plotted on a map of the axial traces (Fig. 14). The east-west crosssections (Fig. 12, sections $\mathrm{A}-\mathrm{C}$ ) are perpendicular to the $\mathrm{F}_{\mathrm{Z}}$ fold axes. The north-south cross-sections (Fig. 12, sections 1 and 2) are parallel to the stretching lineations and also correspond to the classical sections published by Jenny et al. (1923), later actualised and completed by Nagel et al. (2002a) for the southern part. The cross-sections of the frontal part of the nappe (Fig. 12, sections 3 and 4) are perpendicular to the $\mathrm{F}_{\mathrm{L}}$ and $\mathrm{F}_{\mathrm{C}}$ fold axes.

The occurrences of the Internal Mesozoic and the Permian Zervreila orthogneiss are the main markers of the nappe geometry. The Internal Mesozoic of the Adula nappe has been studied in several localities of the northern part of 
Fig. 10 Cross-section of the Plattenberg area. The crosssection trace is indicated in Fig. 9

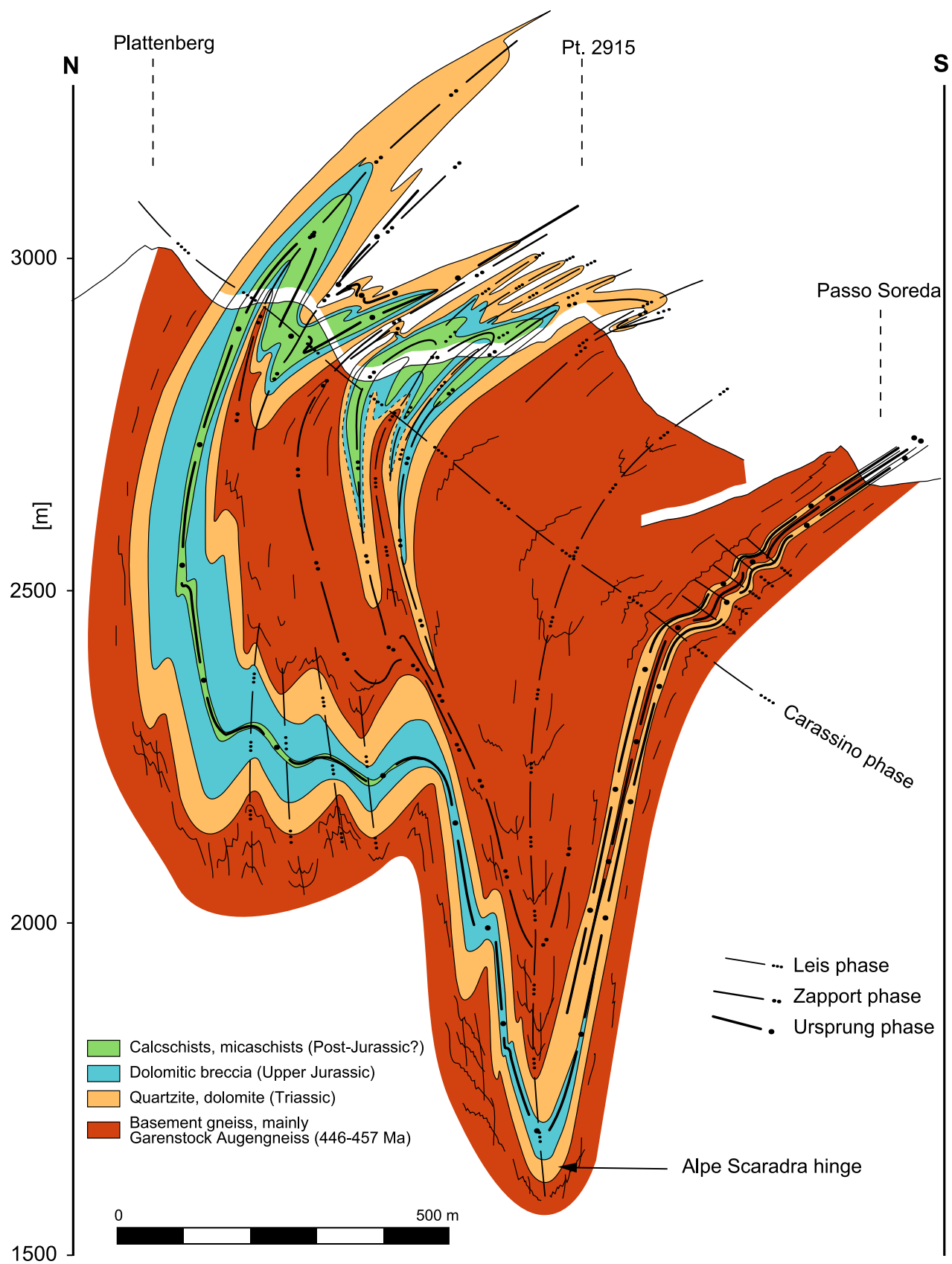

the nappe, and stratigraphic sections are given in Online Resources 1 and 2 .

The geometry at nappe scale unveils some structural relationships that are locally obliterated by the intense Zapport phase deformation at outcrop scale; e.g. the discordant intrusive geometries of the Zervreila orthogneiss is clear at map scale (Egli 1966; Löw 1987; Cavargna-Sani et al. 2014) but cannot be detected at smaller scale.

The earliest nappe-scale deformation is outlined by the Internal Mesozoic. The development of the Internal Mesozoic is essentially due to a ductile folding related to the Ursprung phase as demonstrate by the structural relations at outcrop-scale. The meter-size boudins of the Internal Mesozoic on the top of the central Adula are aligned on the same structural planes and restricted to the upper part and the frontal part of the nappe. The lithological boundaries and the Internal Mesozoic on the top of the central part of the nappe have a steeper dip angle to the north than the upper nappe boundary (Fig. 12, section 1). This nappe-scale geometry has also been represented in previously published cross-sections (i.e. Jenny et al. 1923) Nagel (2008), named it "forward-dipping-duplex geometry". This geometry is compatible with a the top-to-S ductile shear (Ramsay 1980). 


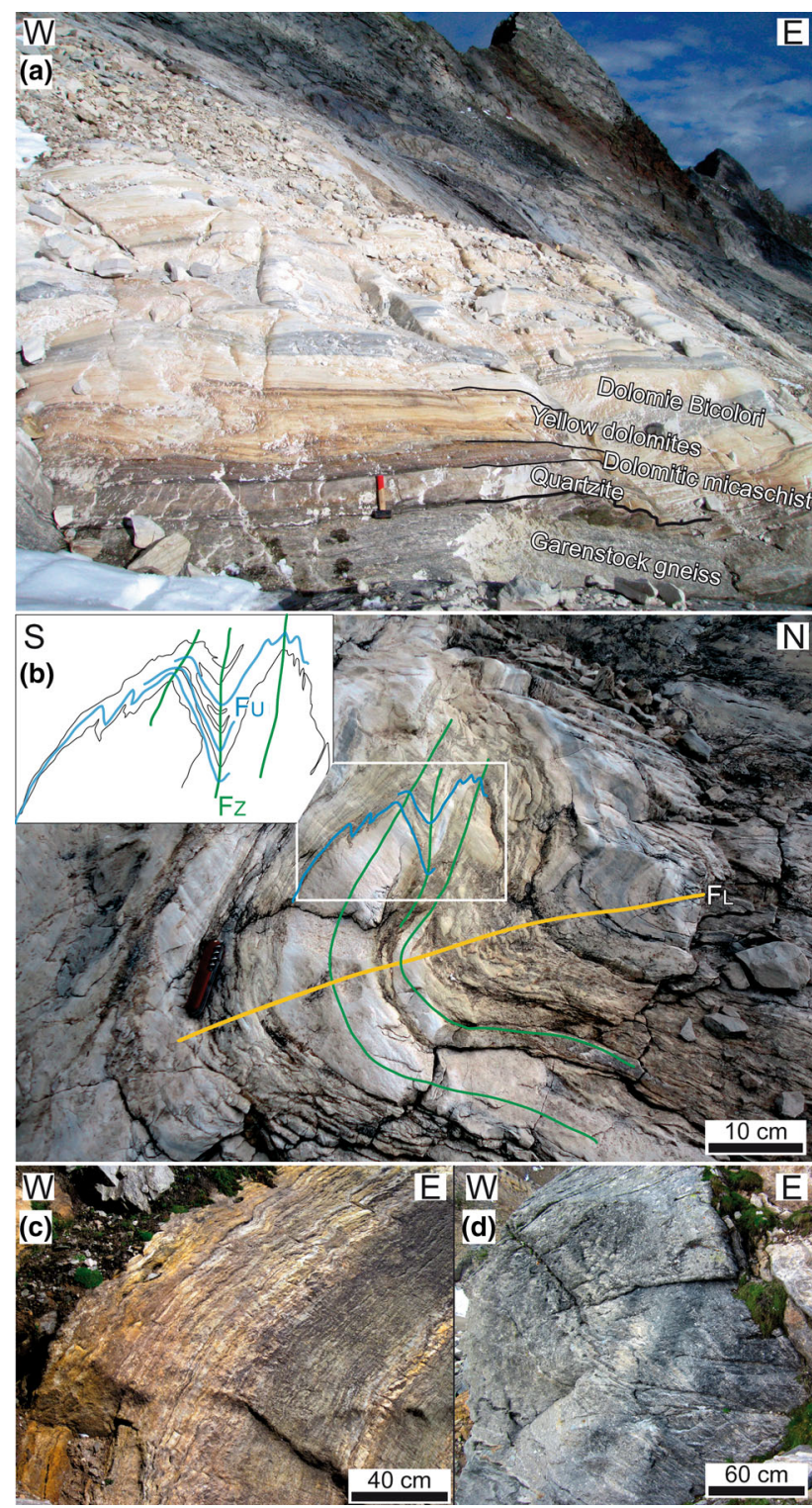

Fig. 11 Outcrop-scale structures in the Plattenberg area. a Basementcover contact (721870/157500). b Fold interference for $F_{U}, F_{Z}$ and $F_{L}$ (721790/157520). c Leis fold and cleavage in dolomites (721510/ 156740). d Leis fold and cleavage in the Garenstock augengneiss (721550/157120)

The Adula nappe has a Triassic overturned sedimentary cover (Fig. 15) on a segment of the inverted limb of the Adula nappe (Fig. 12, section 2). This part of the inverted limb is the only segment of the nappe boundary with a recognizable and developed autochthonous sedimentary cover that is not part of the Internal Mesozoic. To the south, the Forcola line (Fig. 1) is also a discordant structure at the top of the nappe. It is not part of the structure described above because the Forcola line is a much younger structure (Meyre et al. 1998; Ciancaleoni and Marquer 2006).
$\mathrm{F}_{\mathrm{Z}}$ forms an isoclinal recumbent west-closing fold at the nappe scale (Fig. 12, section A). This section demonstrates that the foremost geometry of the northern Adula nappe is a Zapport phase fold-nappe. In the frontal part, the synclines formed by the Internal Mesozoic are related to $\mathrm{F}_{\mathrm{U}}$ and also $\mathrm{F}_{\mathrm{Z}}$ synclines (Fig. 12, sections 1, 3 and 4 ). The connection of these synclines with the nappe boundary is not observed.

Large map-scale $F_{L}$ are essentially developed in the northwest Adula nappe (Fig. 12, sections 1-4). In contrast to the previous phases, $\mathrm{D}_{\mathrm{L}}$ is not restricted to the Adula nappe and also affects the tectonic contact with the adjacent tectonic units. In the frontal part of the nappe, $\mathrm{F}_{\mathrm{L}}$ and $\mathrm{F}_{\mathrm{Z}}$ produce several complex fold interference patterns (Fig. 12, sections 1, 4, B, C). The staurolite isograd $\left(\mathrm{St}_{1} /\right.$ $\mathrm{St}_{2}$ isograd of Nagel et al. 2002b, Fig. 14), indicative of the Barrovian metamorphism, crosscuts the central Adula nappe. It is not deformed and, therefore, postdates most of the nappe deformation. The $\mathrm{F}_{\mathrm{C}}$ antiform is obvious at the front of the nappe (Figs. 12, sections 1-4, 10). This late folding affects the overlying nappes, but it disappears downward and does not propagate in the nappes underlying the Adula nappe (Fig. 12, section 2).

\section{Tectonic evolution of the northern Adula}

\subsection{Leis and Carassino-nappe front and post-nappe folding}

The younger Leis and Carassino deformation phases postdate the deformation phases related to nappe emplacement. The Carassino antiform is a northwest-vergent nappe-scale fold (Fig. 16a) in the frontal part of the Adula nappe and in the nappes directly on top of it. This fold corresponds to the last north-directed ductile shear at the Adula nappe front. Deformations related to back-folding, such as the Claro and Cressim folds (Nagel et al. 2002a), are not observed in the northern Adula nappe. The Leis deformation phase is characterised by nappe-scale northwest-vergent folds (Fig. 16b) visible at the front of the nappe. In the central part of the nappe, the folds are smaller, restricted to the outcrop scale and north-vergent. This observation suggests a north-directed ductile shear as a continuation of the Zapport phase. These folds partially refold the nappe boundary, suggesting that they post-date nappe emplacement, at least for the final steps of the Leis phase deformation.

The structural orientations (Fig. 13) reveal a reorientation of the Zapport phase structural features in the northern part of the nappe. In the central part of the nappe, the stretching lineation directions and the fold axes related to the Zapport phase have a constant north-south orientation. The orientation of the structure becomes more variable 


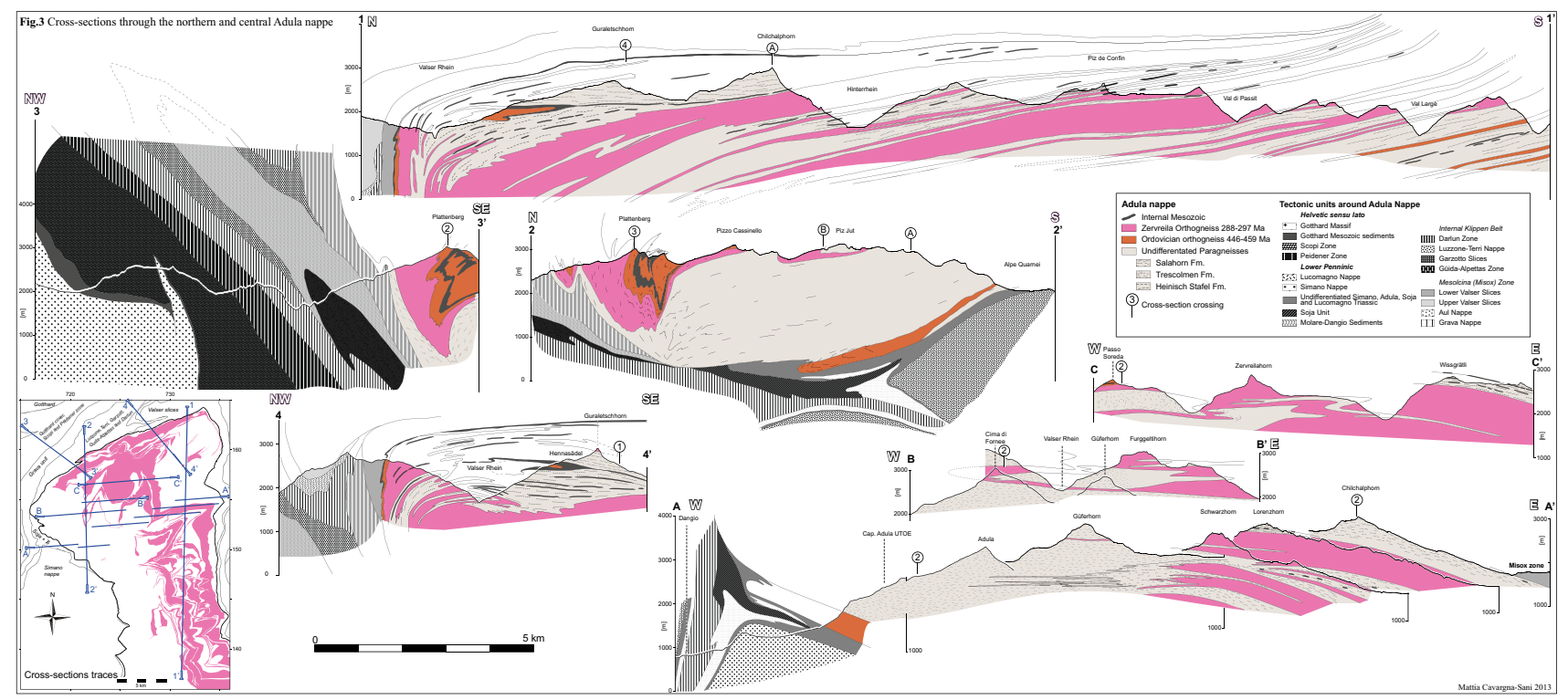

Fig. 12 Synthesis of the internal structure of the Adula nappe, and the tectonic units in its surroundings. A high-resolution version of this figure appears as Electronic Supplementary Material with the online version of the article and can be found as a fold-out at the back of the printed issue

going north, where the Zapport phase linear features are scattered around a northeast-southwest orientation. This reorientation suggests a post-Zapport dextral ductile shear in the northern part of the nappe that turns the original Zapport features. This dextral shear is most likely related to the Leis deformation phase, given that the Leis phase fold axes are not reoriented.

The Barrovian metamorphic conditions in the Adula nappe, the greenschist facies in the north and the amphibolite facies in the south (Fig. 14) were achieved by decompression from the high-pressure metamorphic peak without significant reheating (see the discussion in Nagel 2008). The Leis deformation phase predates the peak Barrovian event and is also associated with decompression (Löw 1987; Nagel 2008; Nagel et al. 2002a). The Carassino deformation phase is not related to specific metamorphic conditions because no specific mineral growth is associated with it.

The age of the Leis deformation postdates the major decompression events at $\sim 32 \mathrm{Ma}$ (Hermann et al. 2006; Liati et al. 2009) and predates the backfolding event occurring in the southern Adula (the Novate granite postdates the backfolding at $\sim 25 \mathrm{Ma}$, Liati et al. 2000). The Carassino antiform (Fig. 16e) is younger than the Leis deformations, but a more precise age cannot be suggested.

\subsection{Kinematic interpretation of the nappe emplacement}

The Zapport deformation phase produces the most pervasive structures in the entire Adula nappe (see also Löw 1987; Nagel 2008; Nagel et al. 2002a). This phase represents the main schistosity that carries a north-south stretching lineation. The Zapport phase is associated with a top-to-N movement attested by widespread and clear shear sense indicators. The overall Zapport phase fold-geometry of the central part of the Adula nappe suggests a fold-nappe formation related predominantly to this phase.

We interpret the Zapport deformation as the consequence of a ductile north-directed fold-nappe emplacement (Fig. 16b, c). The exhumation and nappe emplacement of the Adula during the Zapport phase is concomitant with decompression from the peak pressure $(1.0-1.3 \mathrm{GPa}$, $450-600{ }^{\circ} \mathrm{C}$ in the Vals region and $\sim 2.2 \mathrm{GPa}, \sim 650{ }^{\circ} \mathrm{C}$ in the Alp da Trescolmen) through a single P-T loop (Löw 1987; Meyre and Puschnig 1993; Meyre et al. 1999; Nagel et al. 2002b; Zulbati 2008). Therefore it postdates the highpressure event of $\sim 38 \mathrm{Ma}$ (Herwartz et al. 2011).

The Ursprung phase is mainly characterized by Internal Mesozoic synclines in the upper and frontal part of the nappe. This phase has obvious folding interferences with the Zapport phase. The Zapport phase strongly overprints the outcrop-scale Ursprung structures so that no stretching lineation and shear-sense indicator can be clearly related to the Ursprung phase. Nevertheless, the north-dipping geometry of the Internal Mesozoic synclines linked to the Ursprung phase agrees with a top-to-S ductile shear on the top of the nappe (Fig. 17b). In this situation, the peculiar geometry at the top of the nappe results from the combination of the top to the south Ursprung shear and the top to the north Zapport shear. It is not caused by processes resulting in a tectonic mélange, as previously suggested (e.g., Tromsdorff 1990). The opposite shear senses can 


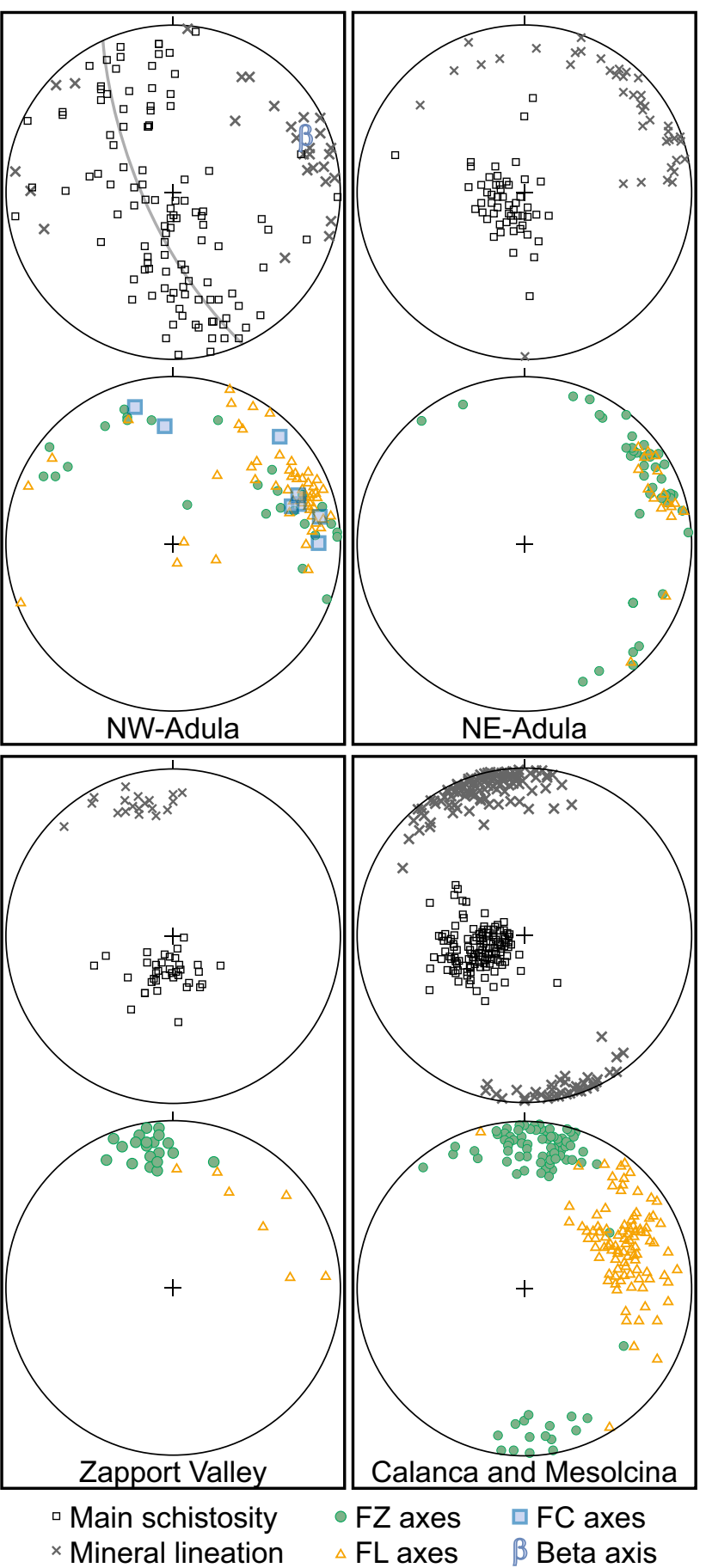

Fig. 13 Stereographic projections of structural data from the northern Adula nappe (for locations of subareas, see Fig. 14b). The lineations in the northwest Adula are principally attributed to $\mathrm{L}_{\mathrm{L}}$; the lineations are not separated between different deformation phases because $\mathrm{L}_{\mathrm{L}}$ is nearly indistinguishable from $\mathrm{L}_{\mathrm{Z}}$. The best-fit girdle and the beta axis indicating the fold axis of the Carassino-antiform (plunging $14^{\circ}$ towards $066^{\circ}$ ) are shown. Lambert equal-area projection, lower hemisphere

explain why the Ursprung phase was not completely obliterated by the later pervasive Zapport phase in the upper limb of the nappe. Instead of being completely parallelized by high strain, the discordance between the Ursprung-related Internal Mesozoic synclines and the upper boundary of the nappe was preserved or even increased by the opposite shear related to the Zapport phase. The metamorphic conditions in relation to the Ursprung phase have not been established, consequently the kinematic interpretation is based on structural criteria (mainly fold superimposition) and not on crystallisationdeformation relationships.

The inverted limb of the nappe exhibits a stratigraphic contact of the cover series, in contrast to the frontal part and the top of the nappe. The Internal Mesozoic synclines and boudins are also totally absent from overturned limb of the nappe. We interpret the geometry of the cover series in the Adula nappe (Internal Mesozoic) as the result of a topto-S shear forming the deep synclines in the upper normal limb (Internal Mesozoic, "forward-dipping duplex geometry") associated with the formation of an inverse limb by top-to-N shearing. We associate the initiation of the Adula fold-nappe with an extrusion (opposite shear sense in each limb of the nappe) during the Ursprung phase (Fig. 17b).

The deformation mechanism that created the Middle Penninic nappes and the North Penninic sedimentary nappes (on the top of the Adula nappe) points to nappe emplacement supported by narrow basal shear zones (Schmid et al. 1996; Schreurs 1993; Mayerat Demarne 1994; Scheiber et al. 2012). The deformation mechanism in the Lower Penninic basement nappes (including the Adula nappe) points to the formation of fold-nappes (Argand 1916; Steck 1990; Escher et al. 1993; Schmid et al. 1996; Rütti 2003), which suggests that the Middle Penninic nappes (Suretta, Tambo and Schams), the North Penninic sediments and the units forming the Piz Terri-Lunschania zone are detached from their substratum and accreted in the accretion prism due to narrow basal shear zones. This early detachment prevented deeper subduction. These observations illustrate the following two types of Alpine nappes as suggested by Escher et al. (1993), which can also be applied to the classic Central Alpine section (Schmid et al. 1996): (1) detachment and accretion in the subduction prism of the thrust-nappe and (2) ductile deformation at the nappe scale leading to fold-nappes. In a subduction zone, we can imagine the detachment of several "superficial" units, while the rest of the slab continues its subduction until it is deep and warm enough to form a fold-nappe. We suggest that the kinematics of the extrusion of these fold nappes are a combination of pure and simple shear driven by buoyancy forces in a subduction channel caused by the light continental crust subduction (beginning of the subduction of the European crust). The first (southernmost) continental crust to undergo ductile deformation, without basal detachment, in the eastern Lepontine transect is the Adula nappe (Fig. 16b). The top-to-S shear of the Ursprung 


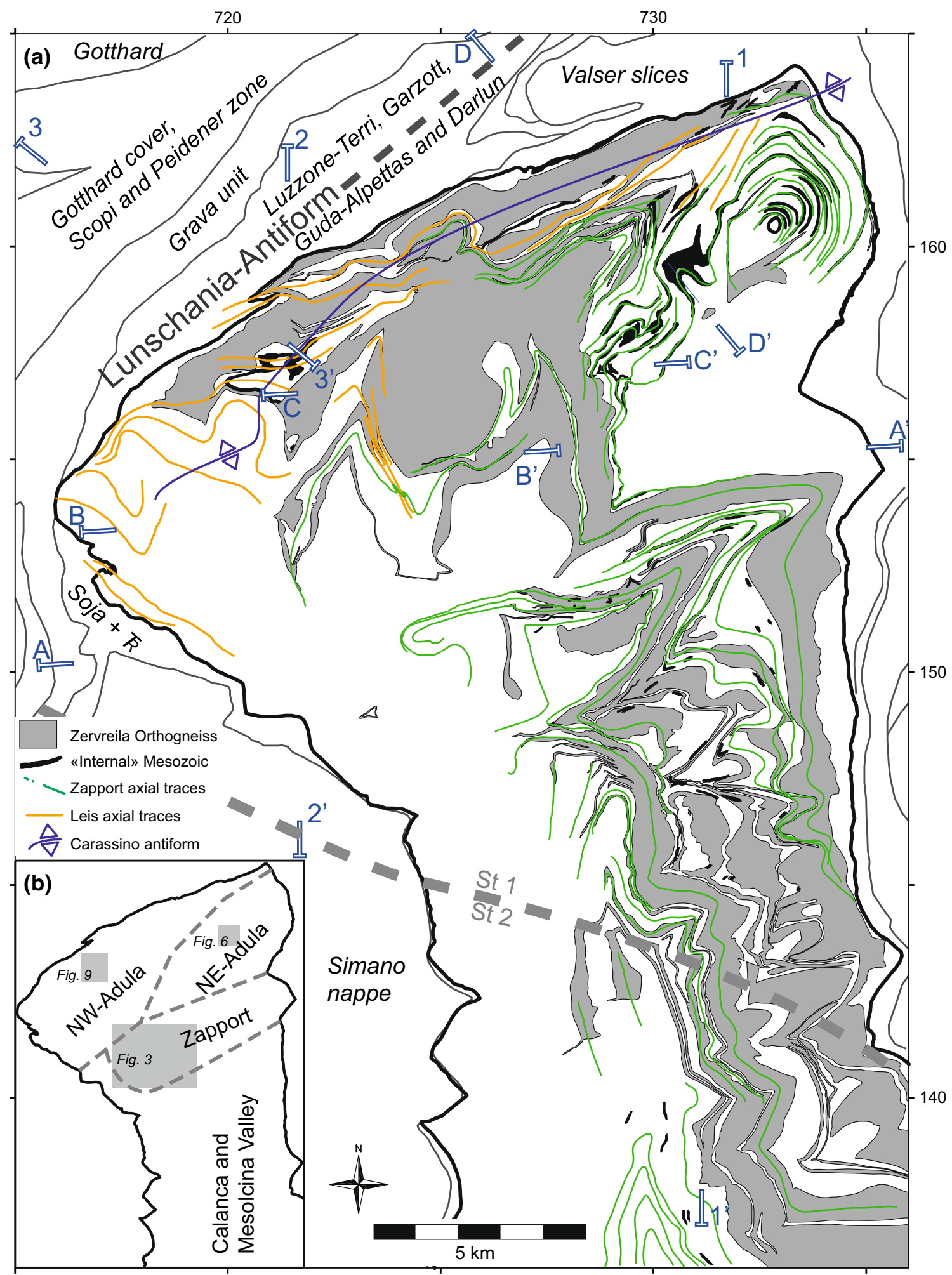

Fig. 14 Axial traces of the principal folds. $F_{Z}$ axial traces are not exhaustively represented. The $\mathrm{F}_{\mathrm{U}}$ axial trace are not represented, but coincide with the "Internal Mesozoic" slices where these are present. The location of the cross-section shown in Fig. 12 are marked in blue. $\mathrm{St}^{1} / \mathrm{St}^{2}$ indicates the northern boundary of the regional amphibolite facies isograd in the Adula nappe (Nagel et al. 2002b). The coordinate system is the kilometric Swiss grid ( $\mathrm{CH}$ 1903). b Structural measurement subareas (Fig. 13). Grey rectangles indicate the position of the detail maps (Figs. 3, 6, 9) 


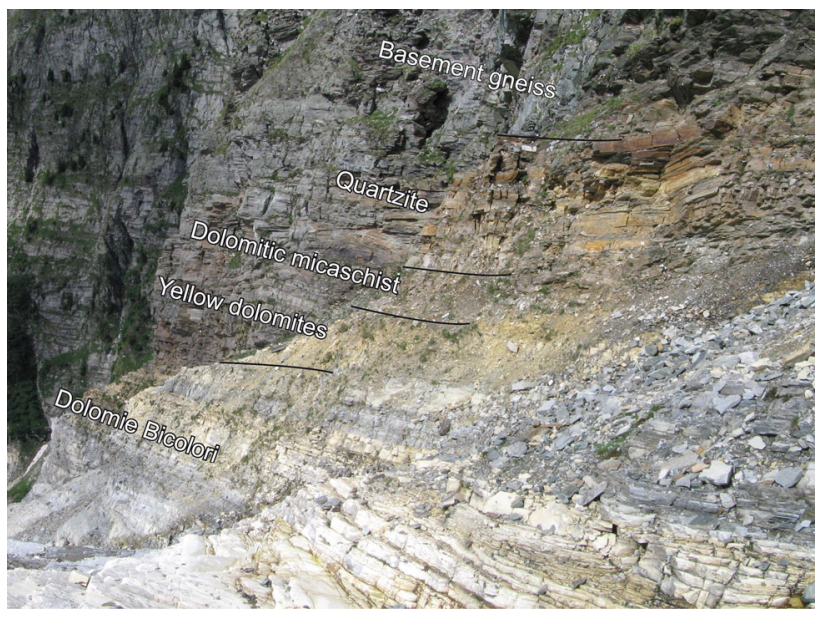

Fig. 15 Basement-cover contact on the inversed limb of the Adula nappe. Val Soi (719960/148800)

phase is almost certainly a result of the peculiar position of the Adula nappe.

\subsection{The Mesozoic Adula paleogeographic domain}

The detailed study of the Adula cover reveals a coherent sedimentary sequence in which several stratigraphic groups can be defined. For the following discussion, the reader is referred to Online Resources 1 and 2, where several stratigraphic sections are described.

The quartzite, ubiquitous at the base of the Mesozoic sections, represents the transgression and the beginning of the first sedimentary cycle. The quartzite is also the most fundamental marker evidencing the autochthony of the cover with respect to the basement. Stratigraphically overlying the quartzite, a metre-thick meta-limestone with thin dolomitic beds is observed in the sections of Usser Rossbodma, Hohbüel, and the Inder Rossbodma. It is interpreted as a reduced equivalent of the St. Triphon Fm. (Baud 1976, 1987). On top of this sedimentary group, the Dolomie Bicolori Fm. (Bianconi 1965; Galster et al. 2012) is constant and typical in every section.

This first sedimentary cycle of the Adula nappe has to be assigned to the Triassic-facies of the North-Penninic realm zone (Galster et al. 2012). This facies was most probably deposited between the Helvetic and the Briançonnais Triassic domains (Fig. 18).

Lower and early Middle Jurassic sediments are not observed in the Adula nappe. These sediments are, however, well developed in the nappes that represent the adjacent paleogeographic domains (Baumer et al. 1961; Steinmann 1994, Galster et al. 2012). The lack of these sediments in the Adula nappe is possibly due to later emersion and erosion. The Adula domain could represent a mid-Jurassic rise at the southern limit of the more or less normal European crust, immediately north of the hyperextended margin (Fig. 18). Emersions in the Alpine context are generally observed during the Middle Jurassic and are linked to the uplift of horst-like blocks in an extensional regime, e.g., in the Briançonnais domain (Baud and Masson 1975), the Teggiolo zone (Matasci et al. 2011) and the nearby Garzott slices (Galster et al. 2012).

A second group of metasediments originally covering the basement of the Adula nappe is visible in the Plattenberg and the Hennasädel sedimentary series. The Plattenberg breccia and the Hennasädel post-Triassic sandstone represent a transgressive sedimentary cycle over an eroded surface of the Triassic Dolomie Bicolori (Cavargna-Sani et al. 2010). The Plattenberg breccia is most likely a sedimentary formation related to a local depocenter, as suggested by the abundance of angular elements. These sediments reveal the existence of a paleorelief. The Hennasädel is the only section that displays a thick, purely calcitic, marble formation in the post-Triassic sequence. A thinly bedded sandy marble occurs at its base and records a transition from the sandstone to the pure massive marble. Above the pure marble, we observe an alternation of beds of yellowish impure marble and calcschist. A similar transition is observed in the Helvetics (e.g., Anatra 1986). It is comparable to the Quinten Formation in the Helvetics, the Sevinera marble in the Teggiolo zone (Matasci et al. 2011), and the massive Malm limestone of the Subbriançonnais domain. This second sedimentary cycle cannot be dated in the Adula nappe; by parallelism to the nappes in a similar paleogeographic position (cited above), we ascribe the deposition of this second sedimentary group to Middle Jurassic-Berriasian time.

A third stratigraphic group is deposited over a discordant surface detectable at the cartographic scale (Online Resource 1). The unconformity at the base of this third cycle is comparable with those occurring below the North Penninic Flysch (e.g., Niesen nappe, Badoux and Homewood 1978; Valais s.s. of the Tarentaise, Antoine 1971; Teggiolo zone, Matasci et al. 2011; Monte Leone cover, Carrupt 2003; and in the Helvetic Wildhorn nappe, Stacher 1980). The third sedimentary cycle is dominated by detrital rocks and is grouped under the loose term "flysch" s.l., although real turbidites were never described. Most likely, these sediments are the result of complex mechanisms of sedimentation that combine the effects of both downslope and bottom currents. Noteworthy is the presence of pebbles of pure limestone (similar to the pure marble of the Hennasädel section), suggesting the erosion and resedimentation of the Upper Jurassic limestone and pointing to a post-Upper Jurassic age of these formations. However, the sedimentation of the flysch group of the Adula nappe cannot be correlated directly to the typical North Penninic Flysch. The Niesen Flysch (Ackermann 1986), the 

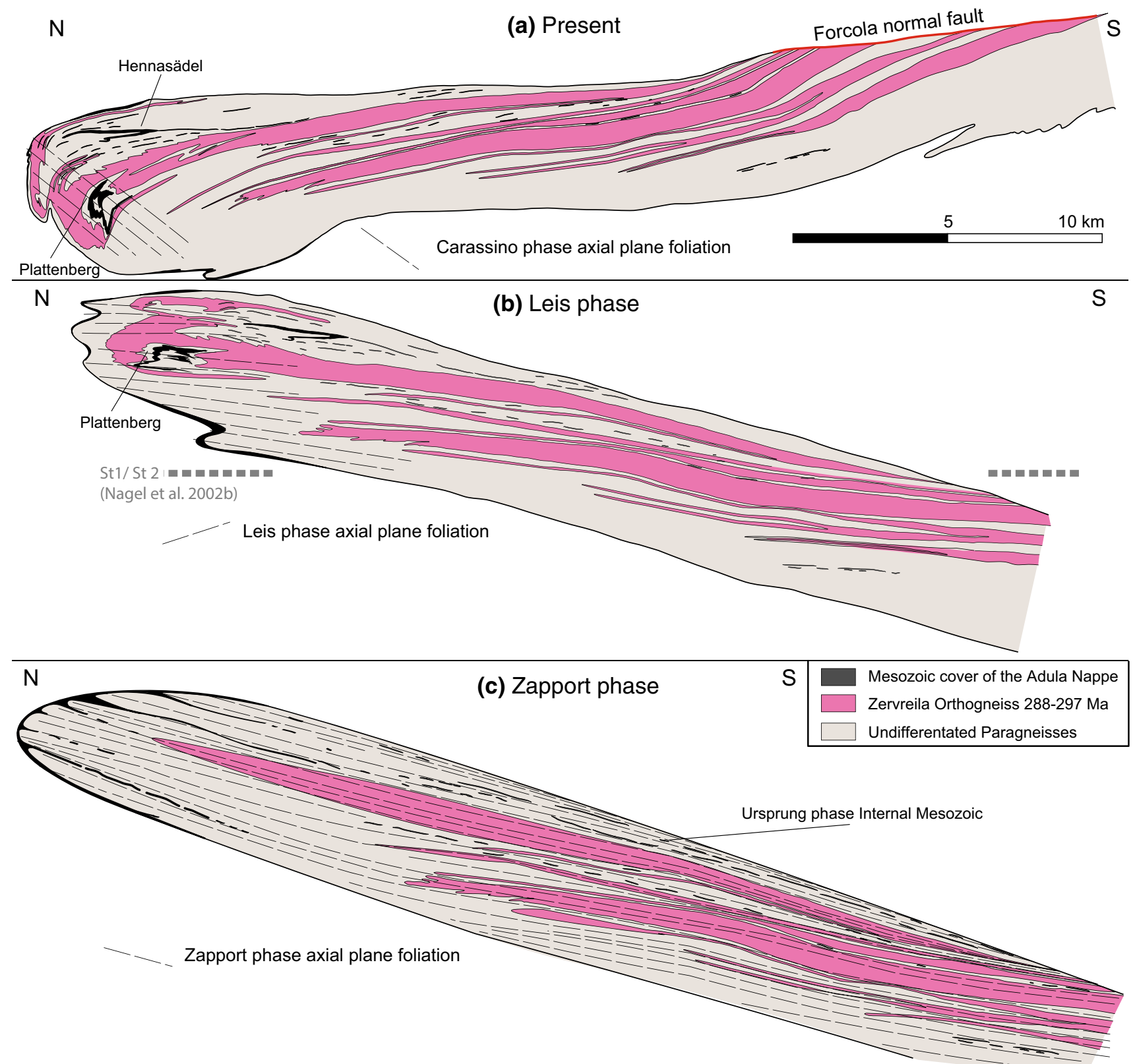

Fig. 16 Structural evolution of the Northern Adula nappe. a Present day geometry. The cross-section is obtained by combining the sections of Fig. 12. b Leis phase $\sim 28 \mathrm{Ma}$. Northern Adula nappe; structures of the Leis phase. Geometry obtained by subtraction of the Carassino structures. The tilting angle of the nappe is drawn assuming a flat isograd of the Barrovian metamorphism. c Zapport phase

Gurnigel-Schlieren Flysch (Trümpy 2006) and the Arbalatsch Flysch (Ziegler 1956) are thick and rather monotonous stacks of typical turbidites. The Adula "flysch" most likely is to be compared with the well-bedded and predominantly fine-grained siliclastic sediments of the Sion-Courmayeur zone (Trümpy 1954; Jeanbourquin and Burri 1991) or the lower part of the Teggiolo calcschists (Matasci et al. 2011).
32 Ma. Northern Adula nappe; structures of the Zapport phase. Geometry obtained by subtraction of the Carassino and Leis structures. Internal Mesozoic boudin trails are the result of the Ursprung phase synclines. Unconformity between trails and upper nappe limit is still visible

The cover series represent the most important markers for the study of the Alpine structures of the Adula nappe. Primarily, our observations exclude the postulate that the northern Adula nappe represents an Alpine tectonic mélange, mixing different elements originating from several paleogeographic domains. Additionally, the stratigraphy of the Mesozoic cover of the Adula nappe reveals a complex Jurassic syn-rift sequence (Cavargna-Sani et al. 2010; 


\section{(a) Zapport deformation: $\sim 32 \mathrm{Ma}$}

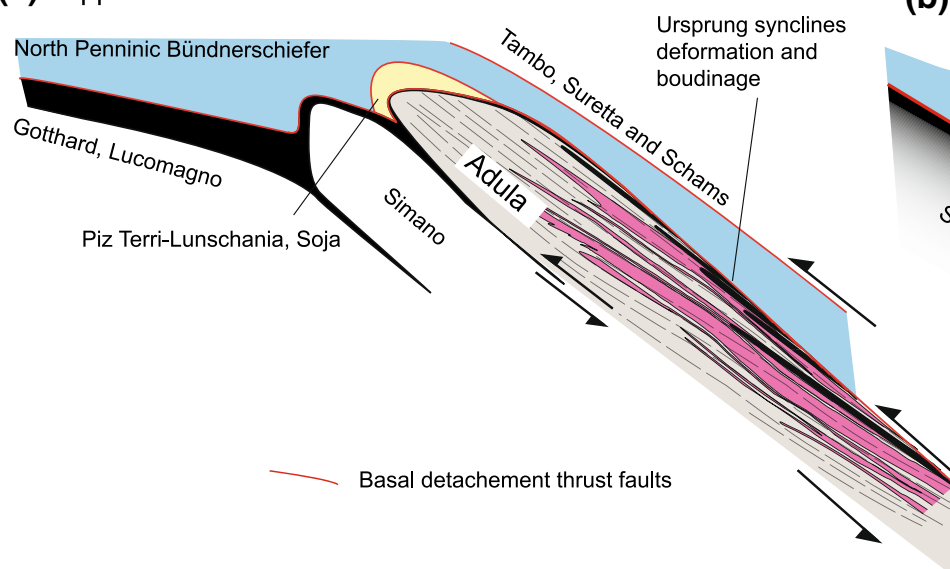

(b) Ursprung deformation

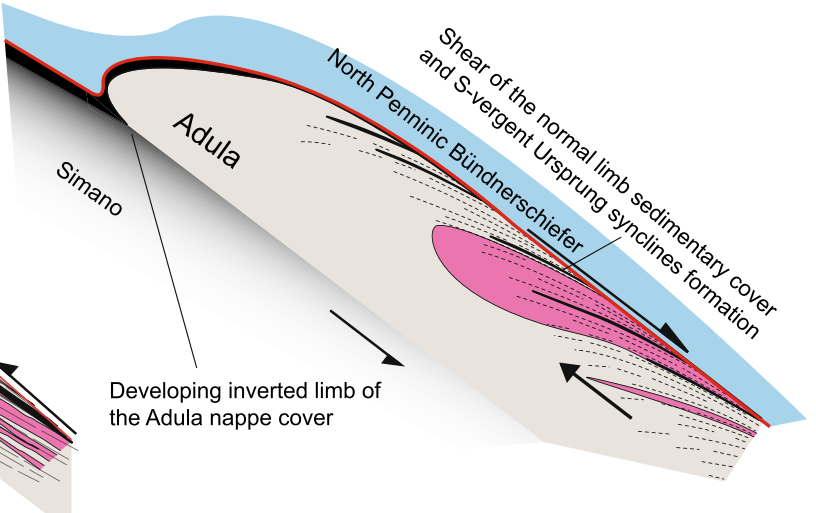

Fig. 17 Interpretation of the kinematics of the northern Adula nappe. a Zapport phase $\sim 32 \mathrm{Ma}$. Kinematic evolution of the northern Adula nappe into the eastern Lepontine nappe stack. The deformation mechanism is essentially a ductile top-to-N shear. b Ursprung phase.
Kinematic evolution of the northern Adula nappe: formation of the south vergent Internal Mesozoic synclines on the top of the nappe and onset of the ductile nappe emplacement

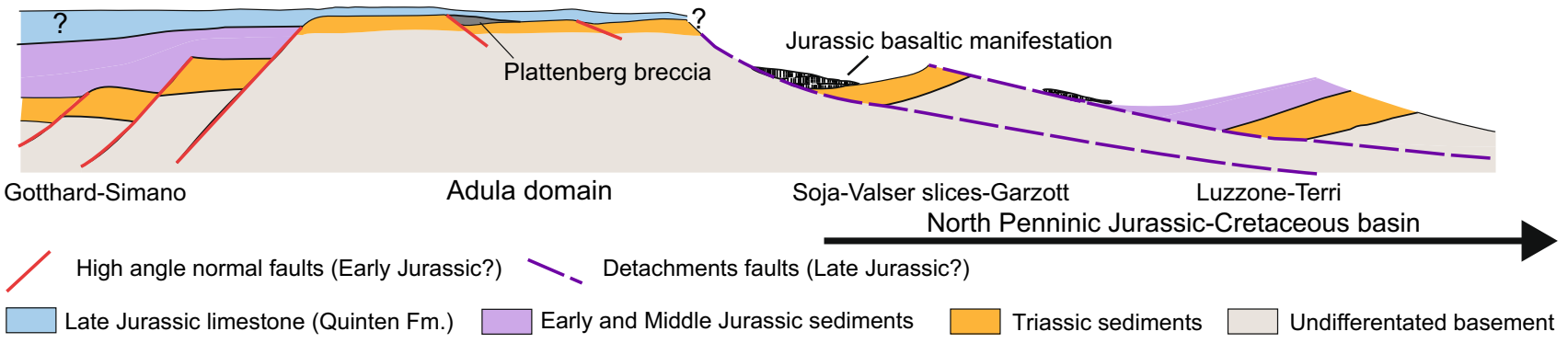

Fig. 18 Early Cretaceous paleogeographic reconstruction of the post-rift Adula nappe domain

Galster et al. 2012). The extensional features inherited from this rifting period definitely influenced the later Alpine structures (e.g., Krayenbuhl and Steck 2009; Bellahsen et al. 2012).

\section{Conclusions}

The northern Adula nappe is characterized by a complex sedimentary history followed by four ductile deformation phases that featured the present-day geometry. The Carassino phase produces the youngest structural features, principally characterized by a $\mathrm{N}$-vergent antiform in the front of the Adula nappe. The Leis phase is related to nappe-scale folding and $\mathrm{N}$-directed shearing which postdate the nappe emplacement. The nappe emplacement occurs during the Zapport phase and the Ursprung phase. The Zapport phase produces the main structural features with isoclinal folding and a strong $\mathrm{N}$-directed shearing that produces a mylonitic fabric. The emplacement of the recumbent, N-closing Adula fold-nappe is ascribed to this deformation phase. The newly defined Ursprung phase is the first Alpine ductile deformation. This phase is responsible for the formation of synclines of Mesozoic autochthonous sedimentary cover deeply folded within the Adula nappe basement. The geometry of these synclines highlights the top-to-S shear occurring during this phase. The detailed study of the Internal Mesozoic reveals a complex Jurassic syn-rift sequence related to extensional structures (i.e. half-graben) that have definitely influenced the later Alpine structures.

The peculiar deformation history, the intense deformation and the presence of high-pressure rock of the Adula nappe is the consequence of the structural position within the Alpine collisional wedge, at the top of the Lower Penninic gneiss-nappes stack. The Adula nappe is part of a major ductile shear zone between the North Penninic sediments and the Briançonnais derived nappes (Tambo and Suretta). Hovewer, the coherent stratigraphy and internal structure exclude to consider the formation of the northern Adula nappe as beeing the result of chaotic Alpine tectonic mélange. 
Acknowledgments This study is supported by the Swiss National Science Foundation, grant no. 200021_132460, and by the Société Académique Vaudoise. We would like to thank L. Nicod for thin section preparation, H. Masson and F. Galster for discussions and comments as well as D. Schreich and A. Pantet for support in the field. We are grateful to the Museo Cantonale di Storia Naturale for authorisation to collect samples in Ticino. We thank T. Nagel and A. Pfiffner for their constructive reviews and G. Milnes and S. Schmid for the editorial handling.

During the course of this project, data and results from the following unpublished works have been used: Diploma theses from Basel University-Baumgartner 1981, Löw 1981, Thüring 1990, Puschnig 1992, Meyre 1993; MSc theses from Lausanne UniversityCavargna-Sani 2008, Galster 2010; Diploma theses from Bern University-Teutsch 1979.

\section{References}

Ackermann, A. (1986). Le flysch de la nappe du Niesen. Eclogae Geologicae Helvetiae, 79, 641-684.

Anatra, S. (1986). Les faciès pélagiques de l'Ultrahelvétique entre Arve et Simme. PhD thesis, Université de Fribourg.

Antoine, P. (1971). La zone des bréches de Tarentaise entre BourgSaint-Maurice (vallée de l'Isère) et la frontière italo-suisse. Travaux du Laboratoire de Géologie de l'Université de Grenoble, Mémoires, 9.

Argand, E. (1916). Sur l'arc des Alpes occidentales. Eclogae Geologicae Helvetiae, 14, 145-191.

Arnold, A., Fehr, A., Jung, W., Kopp, J., Kupferschmid, C., Leu, W., Liszkay, M., Nabholz, W., Van Der Plas, L. Probst, P., Wyss, R. (2007). Blatt 1234 Vals. Geologischer Atlas der Schweiz 1:25000. Karte, 121.

Badoux, H., \& Homewood, P. (1978). Le soubassement de la nappe du Niesen dans la région du Sépey (Alpes vaudoises). Bulletin de la Societé Vaudoise des Sciences Naturelles, 15, 15-23.

Baud, A. (1976). Les terriers de Crustacés décapodes et l'origine de certains faciès du Trias carbonaté. Eclogae Geologicae Helvetiae, 69, 415-424.

Baud, A. (1987). Stratigraphie et sédimentologie des calcaires de Saint-Triphon (Trias, Préalpes, Suisse et France). Mémoire de géologie, Lausanne, 1, 322.

Baud, A., \& Masson, H. (1975). Preuves d'une tectonique liasique dans le domaine briançonnais: faillées conjuguées et paleokarst à Saint-Triphon (Préalpes Médianes, Suisse). Eclogae Geologicae Helvetiae, 68, 131-145.

Baudin, T., \& Marquer, D. (1993). Métamorphisme et dformation dans la nappe de Tambo (Alpes centrales suisses): évolution de la substitution phengitique au cours de la déformation alpine. Bulletin Suisse de Minéralogie et Pétrographie, 73, 285-299.

Baudin, T., Marquer, D., Barfety, J.C., Kerckhove, C., Persoz, F. (1995). Nouvelle interpretation stratigraphique de la couverture mesozoique des nappes de Tambo et de Suretta; mise en evidence d'une nappe de decollement precoce (Alpes centrales suisses). Comptes Rendus de l'Academie des Sciences Serie II Sciences de la Terre et des Planetes, 321.

Baumer, A., Frey, J. D., Jung, W., \& Uhr, A. (1961). Die Sedimentbedeckung des Gotthard-Massivs zwischen oberen Bleniotal und Lugnez). Eclogae Geologicae Helvetiae, 54, 478-491.

Bellahsen, N., Jolivet, L., Lacombe, O., Bellanger, M., Boutoux, A., Garcia, S., et al. (2012). Mechanisms of margin inversion in the external Western Alps: implications for crustal rheology. Tectonophysics, 560-561, 62-83.
Berger, A., \& Mercolli, I. (2006) Tectonic and Petrographic Map of the Central Lepontine Alps. Map sheet 43 Sopra Ceneri 1:100'000. Carta geologica speciale 127. Ufficio Federale di Topografia, Swisstopo.

Berger, A., Mercolli, I., \& Engi, M. (2005). The central Lepontine Alps: notes accompanying the tectonic and petrographic map sheet Sopra Ceneri (1:100’000). Schweizerische Mineralogische und Petrographische Mitteilungen, 85, 109-111.

Bianconi, F. (1965). Resti fossili in rocce mesometamorfiche della regione del Campolungo. Schweizerische Mineralogische und Petrographische Mitteilungen, 45, 571-596.

Bousquet, R., Goffé, B., Vidal, O., Oberhaensli, R., \& Patriat, M. (2002). The tectono-metamorphic history of the Valaisan domain from the Western to the Central Alps: new constraints on the evolution of the Alps. Geological Society of America Bulletin, $114,207-225$.

Carrupt, E. (2003). New stratigraphic, structural and geochemical data from the Val Formazza-Binntal area (Central Alps). Mémoires de Géologie (Lausanne), 41, 118.

Cavargna-Sani, M., Epard, J. L., Bussy, F., \& Ulianov, A. (2014). Basement lithostratigraphy of the Adula nappe: implications for Palaeozoic evolution and Alpine kinematics. International Journal of Earth Science, 103, 61-82.

Cavargna-Sani, M., Epard, J. L., \& Masson, H. (2010). Discovery of fossils in the Adula nappe, new stratigraphic data and tectonic consequences (Central Alps). Bulletin de la Société vaudoise des Sciences naturelles, 92, 77-84.

Ciancaleoni, L., \& Marquer, D. (2006). Syn-extension leucogranite deformation during convergence in the Eastern Central Alps: example of the Novate intrusion. Terra Nova, 18, 170-180.

Dal Piaz, G. V., Martinotti, G., \& Hunziker, J. C. (1972). La Zona Sesia-Lanzo e l'evoluzione tettonico-metamorfica delle Alpi nordoccidentali interne. Memorie della Societá Geologica Italiana, 11, 433-460.

Dale, J., \& Holland, T. J. B. (2003). Geothermobarometry, P-T paths and metamorphic field gradients of high-pressure rocks from the Adula Nappe, Central Alps. Journal of Metamorphic Geology, $21,813-829$.

Egli, W. (1966). Geologische-perographische Untersuchungen in der NW-Aduladecke und in der Sojaschuppe (Bleniotal, Kanton Tessin). PhD Thesis, ETH Zürich.

Engi, M., Todd, C. S., \& Schmatz, D. R. (1995). Tertiary metamorphic conditions in the eastern Lepontine Alps. Schweizerische Mineralogische und Petrographische Mitteilungen, 75(3), 347-369.

Ernst, W. G. (1971). Metamorphic zonations on presumably subducted lithospheric plates from Japan, California and the Alps. Contributions to Mineralogy and Petrology, 34, 43-59.

Ernst, W. G. (1973). Interpretative synthesis of metamorphism in the Alps. Geological Society of America Bulletin, 84, 2053-2078.

Escher, A., Masson, H., \& Steck, A. (1993). Nappe geometry in the Western Swiss Alps. Journal of Structural Geology, 15, 501-509.

Frey, J. D. (1967). Geologie des Greinagebiets (Val Camadra, Val Cavalasca, Val Lariciolo, Passo della Greina). Beitrage zur Geologische Karte der Schweiz, 131, 113.

Galli, A., Le Bayon, B., Schmidt, M. W., Burg, J. P., Caddick, M. J., \& Reusser, E. (2011). Granulites and charnockites of the Gruf Complex: evidence for Permian ultra-high temperature metamorphism in the Central Alps. Lithos, 124, 17-45.

Galli, A., Le Bayon, B., Schmidt, M. W., Burg, J. P., \& Reusser, E. (2013). Tectonometamorphic history of the Gruf complex (Central Alps): exhumation of a granulite-migmatite complex with the Bergell pluton. Swiss Journal of Geosciences, 106(1), $33-62$.

Galster, F., Cavargna-Sani, M., Epard, J. L., \& Masson, H. (2012). New stratigraphic data from the Lower Penninic between the 
Adula nappe and the Gotthard massif and consequences for the tectonics and the paleogeography of the Central Alps. Tectonophysics, 579, 37-55.

Galster, F., Epard, J. L., \& Masson, H. (2010). The Soja and LuzzoneTerri nappes: discovery of a Briançonnais element below the front of the Adula nappe (NE Ticino, Central Alps). Bulletin de la Société vaudoise des Sciences naturelles, 92, 61-75.

Gansser, A. (1937). Der Nordrand der Tambodecke. Schweizerische Mineralogische und Petrographische Mitteilungen, 17, 291-523.

Heim, A. (1891). Geologie der Hochalpen zwischen Reuss und Rhein. Beitrage Geologische Karte der Schweiz, 25.

Heinrich, C.A. (1983). Die reionale Hochdruckmetamorphose der Aduladecke, Zentralalpen, Schweiz. PhD Thesis, ETH Zürich.

Heinrich, C. A. (1986). Eclogite facies regional metamorphism of hydrous mafic rocks in the Central Alpine Adula Nappe. Journal of Petrology, 27, 123-154.

Hermann, J., Rubatto, D., \& Trommsdorff, V. (2006). Sub-solidus Oligocene zircon formation in garnet peridotite during fast decompression and fluid infiltration (Duria, Central Alps). Mineralogy and Petrology, 88, 181-206.

Herwartz, D., Nagel, T. J., Münker, C., Scherer, E. E., \& Froitzheim, N. (2011). Tracing two orogenic cycles in one eclogite sample by Lu-Hf garnet chronometry. Nature Geoscience, 4, 178-183.

Jeanbourquin, P., \& Burri, M. (1991). Les metasediments du Pennique inferieur dans la region de Brigue-Simplon; lithostratigraphie, structure et contexte geodynamique dans le bassin Valaisan. Eclogae Geologicae Helvetiae, 84, 463-481.

Jenny, H., Frischknecht, G., Kopp, J. (1923). Geologie der Adula. Beitrage Geologische Karte der Schweiz, [N.F.] 51.

Krayenbuhl, T., \& Steck, A. (2009). Structure and kinematics of the Jungfrau syncline, Faflertal (Valais, Alps), and its regional significance. Swiss Journal of Geosciences, 102, 441-456.

Kündig, E. (1926). Beiträge zur Geologie und Petrographie der Gebirgskette zwischen Val Calanca und Misox. Schweizerische Mineralogische und Petrographische Mitteilungen, 6, 3-110.

Liati, A., Froitzheim, N., \& Fanning, C. M. (2005). Jurassic ophiolites within the Valais domain of the Western and Central Alps: geochronological evidence for re-rifting of oceanic crust. Contributions to Mineralogy and Petrology, 149, 446-461.

Liati, A., Gebauer, D., \& Fanning, M. (2000). U-Pb SHRIMP-dating of zircon from the Novate granite (Bergell, Central Alps): evidence for Oligocene-Miocene magmatism, Jurassic-Cretaceous continental rifting and opening of the Valais trough. Schweizerische Mineralogische und Petrographische Mitteilungen, 80, 305-316.

Liati, A., Gebauer, D., \& Fanning, C. M. (2009). Geochronological evolution of HP metamorphic rocks of the Adula nappe, Central Alps, in pre-Alpine and Alpine subduction cycles. Journal of the Geological Society, 166, 797-810.

Löw, S. (1987). Die tektono-metamorphe Entwicklung der Noerdlichen Adula-Decke (Zentralalpen, Schweiz). Beitrage Geologische Karte der Schweiz, 161, 1-84.

Mancktelow, N. S. (2008). Tectonic pressure; theoretical concepts and modelled examples. Lithos, 103, 149-177.

Matasci, B., Epard, J. L., \& Masson, H. (2011). The Teggiolo zone: a key to the Helvetic-Penninic connection (stratigraphy and tectonics in the Val Bavona, Ticino, Central Alps). Swiss Journal of Geosciences, 104, 257-283.

Mayerat Demarne, A.-M. (1994). Analyse structurale de la zone frontale de la nappe du Tambo. Materiaux pour la Carte Geologique de la Suisse, 165.

Meyre, C., De Capitani, C., Zack, T., \& Frey, M. (1999). Petrology of high-pressure metapelites from the Adula Nappe (Central Alps, Switzerland). Journal of Petrology, 40, 199-213.

Meyre, C., Marquer, D., Schmid, S. M., \& Ciancaleoni, L. (1998). Syn-orogenic extension along the Forcola Fault; correlation of
Alpine deformations in the Tambo and Adula nappes (eastern Penninic Alps). Eclogae Geologicae Helvetiae, 91, 409-420.

Meyre, C., \& Puschnig, A. R. (1993). High-pressure metamorphism and deformation at Trescolmen, Adula nappe, Central Alps. Schweizerische Mineralogische und Petrographische Mitteilungen, 73, 277-283.

Nagel, T. J. (2008). Tertiary subduction, collision and exhumation recorded in the Adula nappe, central Alps. Geological Society, London, 298, 365-392. Special Publications.

Nagel, T., De Capitani, C., \& Frey, M. (2002a). Isograds and PT evolution in the eastern Lepontine Alps (Graubunden, Switzerland). Journal of Metamorphic Geology, 20, 309-324.

Nagel, T., De Capitani, C., Frey, M., Froitzheim, N., Stünitz, H., \& Schmid, S. M. (2002b). Structural and metamorphic evolution during rapid exhumation in the Lepontine dome (southern Simano and Adula nappes, Central Alps, Switzerland). Eclogae Geologicae Helvetiae, 95, 301-322.

Nimis, P., \& Trommsdorff, V. (2001). Revised thermobarometry of Alpe Arami and other garnet peridotites from the Central Alps. Journal of Petrology, 42, 103-115.

Oberhänsli, R. (1994). Subducted and obducted ophiolites of the Central Alps: paleotectonic implications deduced by their distribution and metamorphic overprint. Lithos, 33, 109-118.

Petrini, K., \& Podladchikov, Y. (2000). Lithospheric pressure-depth relationship in compressive regions of thickned crust. Journal of Metamorphic Geology, 18, 67-78.

Pleuger, J., Hundenborn, R., Kremer, K., Babinka, S., Kurz, W., Jansen, E., et al. (2003). Structural evolution of Adula nappe, Misox zone, and Tambo nappe in the San Bernardino area: constraints for the exhumation of the Adula eclogites. Mitteilungen der Österreichischen Geologischen Gesellschaft, 94, 99-122.

Pleuger, J., \& Podladchikov, Y. Y. (2014). A purely structural restoration of the NFP20-East cross section and potential tectonic overpressure in the Adula nappe (Central Alps). Tectonics, 33, 656-685.

Ramsay, J.G. (1967). Folding and Fracturing of Rocks. McGraw-Hill: New York.

Ramsay, J. G. (1980). Shear zone: a review. Journal of Structural Geology, 2, 83-99.

Ramsay, J. G., \& Allison, I. (1979). Structural analysis of shear zones in a deformed granite from the Pennine zone, Swiss Alps. Schweizerische Mineralogische und Petrographische Mitteilungen, 59, 251-279.

Rück, P. (1995). Stratigraphisch-sedimentologische Untersuchung der Schamser Decken. Beiträge zur geologischen Karte der Schweiz, $167,1-78$.

Rütti, R. (2003). The Tectono-metamorphic Evolution of the Northwestern Simano Nappe: Central Alps, Switzerland. PhD Thesis, ETH Zürich.

Santini, L. (1992). Geochemistry and geochronology of the basic rocks of the Penninic Nappes of East-Central Alps (Switzerland). PhD Thesis, Université de Lausanne.

Scheiber, T., Pfiffner, O. A., \& Schreurs, G. (2012). Strain accumulation during basal accretion in continental collision: case study from the Suretta nappe (eastern Swiss Alps). Tectonophysics, $579,56-73$

Schmalholz, S. M., \& Podladchikov, Y. Y. (2013). Tectonic overpressure in weak crustal-scale shear zones and implications for the exhumation of high-pressure rocks. Geophysical Research Letters, 40(10), 1984-1988.

Schmid, S. M., Pfiffner, O. A., Froitzheim, N., Schönborn, G., \& Kissling, E. (1996). Geophysical-geological transect and tectonic evolution of the Swiss-Italian Alps. Tectonics, 15, 1036-1064.

Schreurs, G. (1993). Structural analysis of the Schams nappes and adjacent tectonic units; implications for the orogenic evolution 
of the Penninic Zone in eastern Switzerland. Bulletin de la Societe Geologique de France, 164, 415-435.

Spicher, A. (1980). Tektonische Karte der Schweiz, 1:500000. Bern: Schweizerische Geologische Kommission.

Stacher, P. (1980). Stratigraphie. Beitrage Geologische Karte der Schweiz: Mikrofazies und Mikropaläontologie der Wang-Formation (Helvetische Oberkreide der Schweizer Alpen). 152.

Steck, A. (1990). Une carte des zones de cisaillement ductile des Alpes Centrales. Eclogae Geologicae Helvetiae, 83, 603-627.

Steck, A., Della Torre, F., Keller, F., Pfeifer, H. R., Hunziker, J., \& Masson, H. (2013). Tectonics of the Lepontine Alps: ductile thrusting and folding in the deepest tectonic levels of the Central Alps. Swiss Journal of Geosciences, 106(3), 427-450.

Steinmann, M.C. (1994). Die nordpenninischen Bündnerschiefer der Zentralalpen Graubündens: Tektonik, Stratigraphie und Beckenentwicklung. PhD thesis, ETH Zürich.

Swisstopo (2012) Sheet 1254 Hinterrhein; vector dataset (used maps see http://www.swisstopo.admin.ch/internet/swisstopo/fr/home/ products/maps/geology/geocover.html). Swisstopo, Bern.

Tromsdorff, V. (1990). Metamorphism and tectonics in the Central Alps: the Alpine lithospheric mélange of Cima Lunga and Adula. Memorie della Societa Geologica Italiana, 45, 39-49.

Trümpy, R. (1954). La zone de Sion-Courmayeur dans le haut Val Ferret valaisan. Eclogae Geologicae Helvetiae, 47, 315-359.

Trümpy, R. (2006). Geologie der Iberger Klippen und ihrer FlyschUnterlage. Eclogae Geologicae Helvetiae, 99, 79-121.
Van der Plas, L. (1959). Petrology of the northern Adula region, Switzerland. Leidse Geologische Mededelingen, 24, 415-598.

Voll, G. (1976). Structural Studies of the Valser Rhine Valley and the Lukmanier Region and their Importance for the nappe Structure of the Central Swiss Alps. Schweizerische Mineralogische und Petrographische Mitteilungen, 56, 619-626.

Wiederkehr, M., Bousquet, R., Schmid, S., \& Berger, A. (2008). From subduction to collision: thermal overprint of HP/LT metasediments in the north-eastern Lepontine Dome (Swiss Alps) and consequences regarding the tectono-metamorphic evolution of the Alpine orogenic wedge. Swiss Journal of Geosciences, 101, $127-155$

Wiederkehr, M., Bousquet, R., Ziemann, M. A., Berger, A., \& Schmid, S. M. (2011). 3-D assessment of peak-metamorphic conditions by Raman spectroscopy of carbonaceous material: an example from the margin of the Lepontine dome (Swiss Central Alps). International Journal of Earth Sciences, 100, 1029-1063.

Ziegler, W. H. (1956). Geologische Studien in den Flyschgebieten des Oberhalbsteins (Graubünden). Eclogae Geologicae Helvetiae, 49, 3-74.

Zulbati, F. (2008). Structural and metamorphic evolution of the phengite-bearing schists of the northern Adula Nappe (Central Alps, Switzerland). Geological Journal, 43, 33-57.

Zulbati, F. (2010). Multistage metamorphism and deformation in high-pressure metabasites of the northern Adula Nappe Complex (Central Alps, Switzerland). Geological Journal, 46, 82-103. 